\title{
CHAPTER. SUPERCRITICAL FLUID EXTRACTION
}

Andrea del Pilar Sánchez-Camargo, José A. Mendiola, Elena Ibáñez*, Miguel Herrero

Laboratory of Foodomics, Institute of Food Science Research (CIAL, CSIC), Campus de

Cantoblanco, Nicolás Cabrera 9, 28049, Madrid, Spain.*elena@ifi.csic.es, Tel.: +34

5 910017956. Fax: +34910017905

Keywords: supercritical fluids, green processes, extraction, plants, by-products, marine products, pharmaceutical products, $\mathrm{CO}_{2}$, Food science, biopesticides, antioxidant activity.

2. Fundamentals of Supercritical Fluid Extraction

2.1. The critical point, physical peculiarities

3. Parameters affecting the extraction processes

3.1. Raw material

3.2. Solubility (Pressure and Temperature)

3.2. Polarity/Use of Modifiers

3.3. Solvent: feed ratio

4. Instrumentation for Supercritical Fluid Extraction

5. Applications

5.1.1. Removal of unwanted compounds

5.1.2. Extraction of functional food ingredients 
Published in Supercritical Fluid Extraction (2014). In: Reedijk, J. (Ed.) Elsevier Reference Module in Chemistry, Molecular Sciences andChemical Engineering. Waltham, MA:

Elsevier. 30-Jun-14 doi: 10.1016/B978-0-12-409547-2.10753-X.

\subsubsection{From plants}

\subsubsection{From marine products}

25

5.1.2.3. From food by-products

5.2. Pharmaceutical

5.3. Other applications

\subsubsection{Heavy metals recovery}

5.3.2 Biopesticides production

30

6. Future trends 


\section{Abstract}

Supercritical fluid extraction (SFE) has become one of the most popular green extraction techniques nowadays since it has demonstrated many advantages compared to traditional or classical extraction processes. Aspects such as improved selectivity, higher extraction yields, better fractionation capabilities and lower environmental impacts have been crucial to the important growth of SFE. In this chapter, fundamentals of SFE are presented together with the most important variables that can affect the extraction process and how to tune them. Moreover, interesting and new applications in different areas such as food science, pharmaceutical and others like, for instance, heavy metals recovery are presented.

\section{Introduction}

45 At present there is an increasing interest in developing processes and methodologies able to comply with the Green Chemistry Principles. Among them, extraction techniques have received a great deal of attention since new approaches are needed to solve some important drawbacks associated to the use of conventional techniques involving the extensive use of toxic organic solvents and high energy usage while providing low selectivity and low extraction yields. These shortcomings can be partially or completely overcome by using newly developed advanced extraction techniques which are faster, more selective towards the compounds to be extracted and, on the top of it, more environmentally friendly. In fact, by using the advanced extraction techniques, the use of toxic solvents is highly limited or greatly reduced. 
This is especially true for Supercritical Fluid Extraction (SFE), a technique based on the use of solvents at temperatures and pressures above their critical points. SFE can be a fast, efficient, and clean method for the extraction of compounds of interest from different matrices while being also an appropriate reaction media, among other important applications, as it will be demonstrated throughout this chapter.

60

\section{Fundamentals of Supercritical Fluid Extraction}

Supercritical fluid extraction is based on the use of a fluid at pressures and temperatures beyond its critical point, in order to achieve significant physical changes that will modify its capabilities as solvent. Although the first experimental works with supercritical

65 phenomena as well with supercritical extraction started back in the $19^{\text {th }}$ century, the increase on the interest of this technique as a potential alternative to conventional solventbased extraction techniques is quite recent. Charles Cagniard de la Tour observed, in $1822^{1,2}$ for the first time, changes in solvents at certain values of pressure and temperature. More than 40 years passed until Thomas Andrews presented the first definition of the term "critical point" in $1869^{3}$. Some years later, the first application of this knowledge to extraction was introduced by Hannay and Hogarth ${ }^{4}$ who reported how solids could get dissolved in solvents at pressures above their critical point. These early works started to show the important implications occurred in a substance that is submitted to pressure and temperature conditions beyond its critical points, mainly derived from important physical

75 changes that are directly responsible for their possible applications in supercritical fluid extraction. In the following section, these physical properties are described in more detail. 


\subsection{The critical point, physical peculiarities.}

The critical point (determined by the critical pressure and temperature) is a particular phase diagram), when the temperature of a solvent is increased at the same time that its pressure and the critical point is reached, a homogeneous supercritical fluid is obtained in which no distinction can be found between phases.

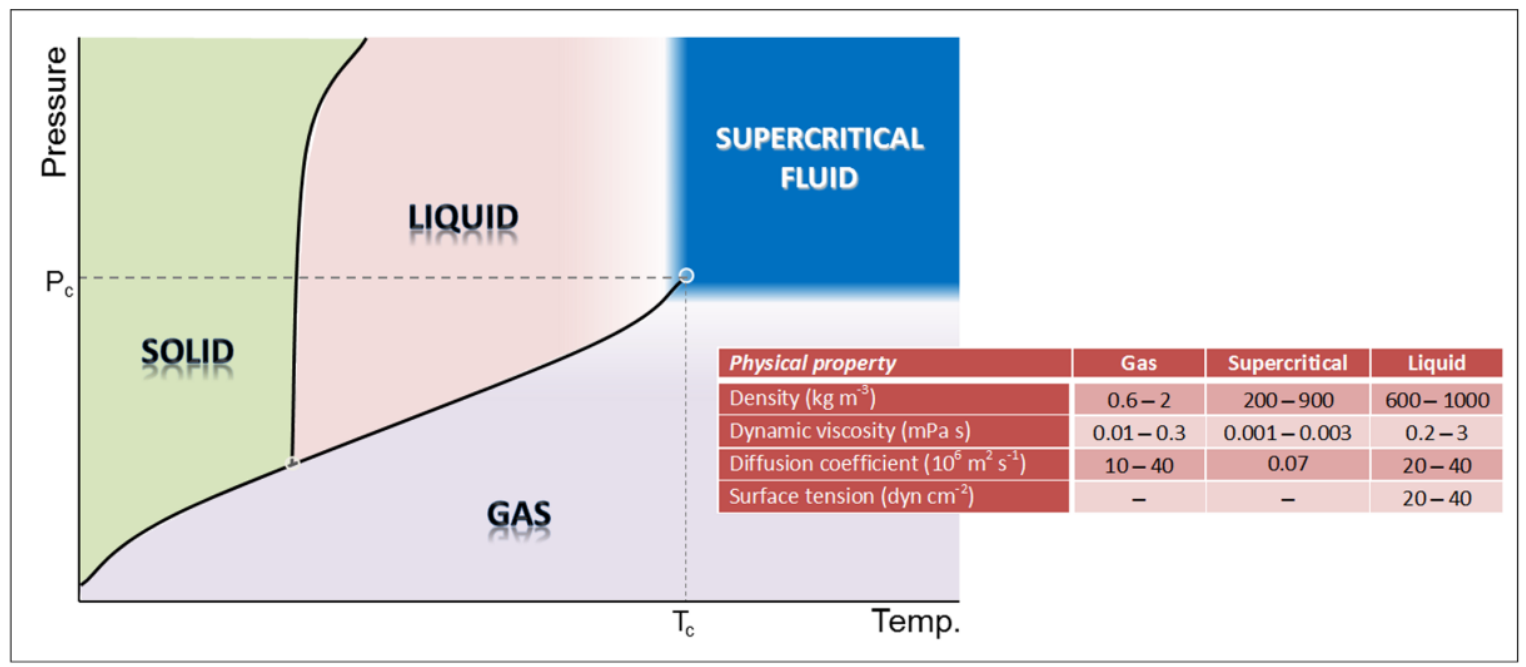

Figure 1. Typical pressure-temperature phase diagram for a given fluid and main physical properties of fluids in the gas, liquid (at room conditions), and supercritical phase. Pc, critical pressure; Tc, critical temperature.

As can be observed in Figure 1, supercritical fluids have mixed properties between those of liquids and those of gases; for instance, the viscosity is similar to a gas whereas its density is close to values found for liquids. On the other hand, its diffusivity is intermediate between that of liquids and of gases. Other important properties are also modified in a supercritical fluid (surface tension, solvent strength, etc.), and will be responsible of the 
properties as a solvent that the fluid will present. Besides, changes in temperature and pressure beyond their critical points will also modify mainly density, effectively changing the solvent capabilities and permitting the achievement of a high degree of selectivity, as it will be described later. For a more in depth description of all the physical modifications produced in a supercritical fluid, readers are referred to other book chapters and review $\operatorname{articles}^{5,6}$. In practice, a wide group of compounds might be used as supercritical fluids provided they are submitted to the appropriate temperature and pressure conditions, from water to organic solvents, among others. In Table 1, some of the most-used supercritical 105 fluids as well as their corresponding critical values are shown. As it can be observed, the critical values greatly change from a substance to another. It is clear that attaining the correct conditions may be very expensive hindering the practical applicability of some of them at pilot and industrial scales. Besides, it is also important to note that some of these substances are not safe. Considering the always increasing awareness for the development of environmentally respectful processes, the use of solvents that demand extremely high amounts of energy to be placed into a supercritical state as well as those that may not be perfectly safe or that are toxic, cannot be justified at all. For these reasons, most of supercritical fluid extraction applications developed nowadays seek to gain advantage of the mild critical temperature and pressure values of carbon dioxide (Table 1). Moreover,

$115 \mathrm{CO}_{2}$ is a green solvent, that is considered a GRAS (generally recognized as safe) solvent for the food industry, is cheap and easily available. Besides, the use of this fluid is not against the limitations established at present for processes generating $\mathrm{CO}_{2}$, as the carbon dioxide employed is not produced ad hoc, but just recycled or collected from other industrial processes. Thus, the use of $\mathrm{CO}_{2}$ in $\mathrm{SFE}$ processes is a way to reuse this important industrial 
by-product. Another important advantage that increases even more the interest on the use of this compound is that $\mathrm{CO}_{2}$ is a gas at room conditions. That means in practice that after the extraction process, when the pressure is relieved, the $\mathrm{CO}_{2}$ is automatically evaporated leaving a perfectly solvent-free extract. On the other hand, the main shortcoming related to the use of supercritical $\mathrm{CO}_{2}$ is its very low polarity. Consequently, its ability to extract 125 highly or medium polarity compounds is rather limited. To overcome this issue, another solvent may be employed together with $\mathrm{CO}_{2}$ at very low proportions, in order to increase the polarity of the supercritical fluid. This added solvent is commonly termed modifier or entrainer. Ethanol or methanol mixed below a $10 \%$ of total $\mathrm{CO}_{2}$ employed are frequently used as modifiers. In the following section, the most-influencing parameters during a supercritical fluid extraction process, including the use of modifiers, are detailed.

Table 1. Critical properties of some of the most-employed fluids used in supercritical fluid extraction.

\section{Critical value}

\begin{tabular}{lcccc}
\cline { 2 - 5 } \multicolumn{1}{c}{ Fluid } & $\begin{array}{c}\text { Solubility } \\
\text { parameter } \boldsymbol{\delta}_{\mathbf{S F C}} \\
\left(\mathbf{M P a}{ }^{\mathbf{1}} \mathbf{2}\right)\end{array}$ & $\begin{array}{c}\text { Density } \\
\left(\mathbf{k g ~ m}^{-\mathbf{3}}\right)\end{array}$ & $\begin{array}{c}\text { Temperature } \\
\left.\mathbf{(}^{\mathbf{0}} \mathbf{C}\right)\end{array}$ & $\begin{array}{c}\text { Pressure } \\
(\mathbf{M P a})\end{array}$ \\
\hline Carbon dioxide & 15.34 & 470 & 31.2 & 7.38 \\
Water & 27.61 & 322 & 101.1 & 22.05 \\
Methanol & 18.20 & 272 & -34.4 & 8.09 \\
Ethylene & 11.86 & 200 & 10.1 & 5.11 \\
Ethane & 11.86 & 200 & 32.4 & 4.88 \\
n-butene & 10.64 & 221 & -139.9 & 3.65 \\
n-pentane & 10.43 & 237 & -76.5 & 3.37 \\
\hline
\end{tabular}




\section{Parameters affecting the extraction process}

Although the selection of the supercritical solvent to be employed may be envisioned as the most-influencing parameter in the extraction, there are a number of important parameters that will significantly affect the solvent strength and the mass transfer processes generated

140 during the extraction and, thus, the outcome of an extraction process. In this section, the most important parameters are briefly described and commented.

\subsection{Raw material}

The raw material is herein defined as the sample to be extracted. For SFE applications

145 either solid or liquid samples might be employed, although in each case the considerations given as well as the instrumentation needed is slightly modified. Considering solid samples, the physical state of the sample may have a strong influence. Particle size and porosity will have a great impact on mass transfer by increasing the surface contact although the humidity of the sample may also hamper the extraction process. In general, the use of dried samples allows attaining better results, although exceptions exist. The correct parameters have to be experimentally set. If the sample size is too small, the formation of preferential channels inside the extraction cell is possible. To avoid this problem, dispersion agents may be used to produce homogeneous extractions.

In the case of liquid samples, counter-current extractions are commonly employed to 155 increase contact between the sample and the supercritical fluid. In these applications, the liquid sample is introduced in the upper part of a packed extraction column whereas the 
supercritical $\mathrm{CO}_{2}$ is introduced from the bottom. By correctly selecting the introducing point (height) as well as the inert column packing material that increases the surface contact, the mass transfer may be optimized.

\subsection{Solubility (Pressure and Temperature)}

Extraction pressure and temperature are probably the most influencing parameters in terms of solubility of a substance in the supercritical fluid. In general, it can be said that higher density of the supercritical fluid will be obtained through an increase in pressure and will

165 lead to an enhanced solubility of sample components. On the other side, an increase on temperature will decrease the density (for a given pressure) although will also promote the transfer of solutes from the sample to the supercritical fluid due to the increment on their vapor pressure. Thus, the selection of the temperature and pressure values to be employed in a process should be carefully made according to the aim of the process as well as the

170 targeted compounds. For natural complex samples, the use of experimental designs that allow the statistical observation of the influence of the different parameters involved as a function of one or more response variables is frequent. Response surface methodology (RSM) or simplex centroid designs (SCD) are often selected.

\subsection{Polarity/Use of Modifiers}

As it has been already mentioned, $\mathrm{CO}_{2}$ is the most-widely employed supercritical fluid nowadays, although its low polarity limits somehow its application to the extraction of low polar/lipophilic compounds. In order to increase the range of potential applications, a modifier might be employed together with the supercritical $\mathrm{CO}_{2}$. Typically, organic 
solvents such as methanol or ethanol are employed as modifiers, at concentration below 10 $\%$ related to the amount of $\mathrm{CO}_{2}$ used for the extraction, although water has been also employed in some applications. This way, it is possible to increase the solubility of sample components with higher polarity. Under these conditions, the physical state of the solvent mixture is more complex, above all because the modifiers might not be in their supercritical state and, thus, different phases may be coexisting during the extraction procedures. Other modifiers have been also used to help in the extraction of very low polarity components, such as oils mixed with $\mathrm{CO}_{2}$ at very low proportions. Lastly, it has to be noted that when using modifiers the possibility of attaining solvent-free extracts is lost because these solvents are not gases at room conditions.

\subsection{Solvent:feed ratio}

The solvent-to-feed ratio to be employed has a critical importance on the supercritical process. Once the pressure and temperature conditions have been defined, it is important to study the effect of the solvent-to-feed ratio or the influence of the $\mathrm{CO}_{2}$ flow rate. This flow 195 rate should be high enough to maximize the extraction yield but also low enough to allow good contact with the sample in order to minimize the amount of $\mathrm{CO}_{2}$ employed, and thus, the operational costs. As it can be deduced, this parameter is particularly important when extracting liquids under counter-current conditions, as in those cases, the ratio will define the contact time allowed between the sample and the supercritical $\mathrm{CO}_{2}$.

\section{Instrumentation for Supercritical Fluid Extraction}


Nowadays, there exists a wide range of commercial instruments from bench-top to industrial scales to carry out supercritical fluid extractions. However, it is common to find applications based on in-house made equipment. The basic instrumentation needed to build a SFE instrument will slightly vary depending on the application, solids or liquids extraction. In Figure 2, the basic components of a SFE extractor are depicted.

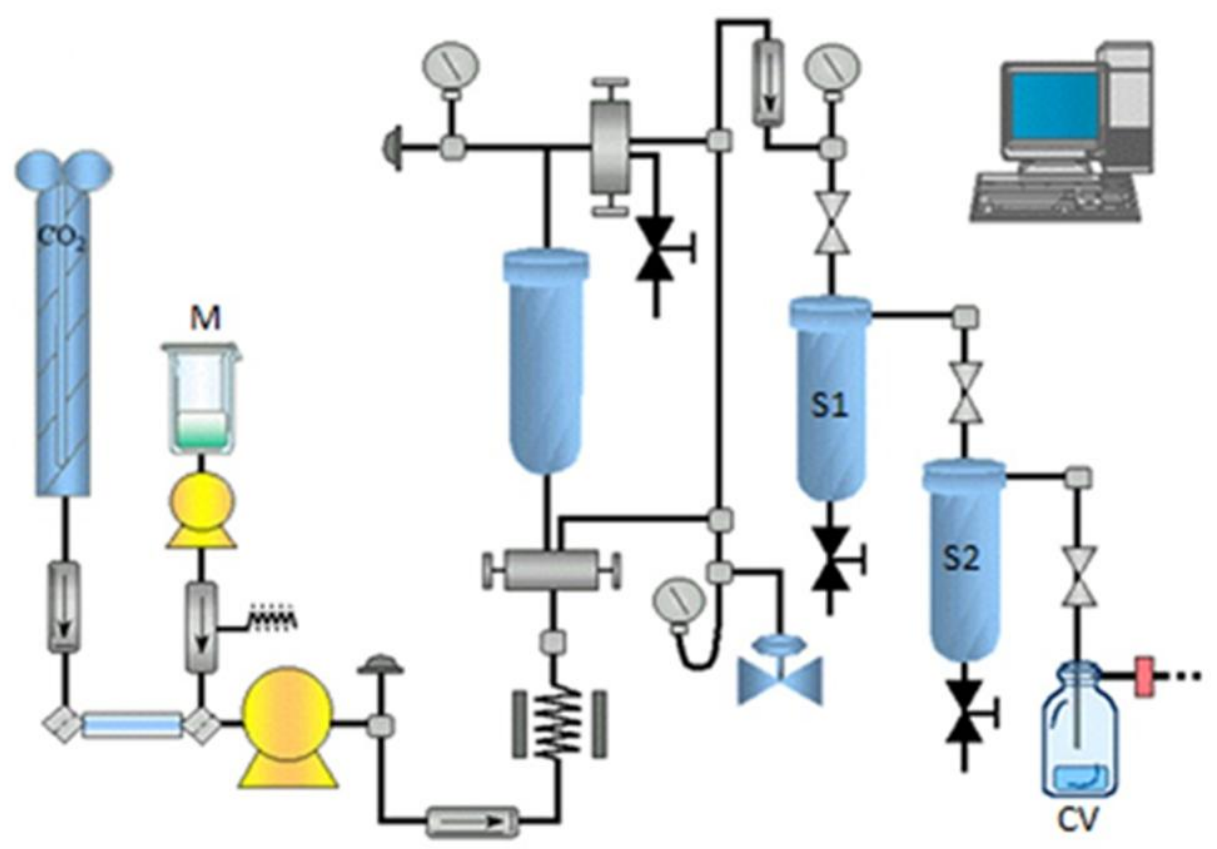

Figure 2. Basic instrumentation needed for a supercritical fluid extraction equipment. M, modifier; $\mathrm{S} 1$, separator 1; S2, separator 2; CV, collection vessel.

The first part of any extractor is devoted to the extraction process itself, composed by a temperature-controlled extraction cell or column able to withstand the high pressures needed to perform the extractions, a $\mathrm{CO}_{2}$ pump and a modifier pump. In the case of liquid samples, the extraction column is frequently equipped with different ports for the introduction of the sample at variable heights. In this latter case, another additional pump is 
needed to introduce the sample into the system. The $\mathrm{CO}_{2}$ pump is the one setting the pressure inside the extraction chamber, so that the supercritical $\mathrm{CO}_{2}$ is always under the desired conditions, which is maintained using a restrictor or a back pressure regulator. The second part of the extractor is focused on extract recovery. It may be composed by a collection cell or by several fractionation vessels in order to perform cascade depressurization.

This basic equipment may be further developed into more complicated systems, for instance installing a system for $\mathrm{CO}_{2}$ recycling or by a variety of devices depending on the scale of the extractor. More details can be found elsewhere ${ }^{6,7}$.

\section{Applications}

\subsection{Food Science}

SFE has been widely used in Food Science; in fact, the first industrial application was the extraction of caffeine from coffee beans by $\mathrm{Zosel}^{8,9}$. Since then a high variety of samples, type of materials, target compounds and procedures have been published.

Two clear trends co-exist in the applications of supercritical fluids to food science: removal of unwanted compounds and extraction of valuable compounds. Both operating trends will be discussed in the following sections.

\subsubsection{Removal of unwanted compounds}

235 When dealing with the removal of unwanted compounds, SFE can be used with different approaches: to remove external toxic compounds from different raw materials and to 
eliminate or reduce unwanted compounds naturally present in the sample. In some cases, both the extraction residue and the extract can be used in different applications. Some examples of each approach are discussed:

$\underline{\text { Removal of external contaminants: }}$

This is probably the main use of SFE as sample preparation. One of the main areas of application of SFE in the last few years has been in food pollutants analysis, mainly pesticide residues and environmental pollutants ${ }^{10}$. A common characteristic of these works is the extremely high selectivity of SFE in the isolation of the low polarity pesticides; this

245 fact makes SFE probably the technique of choice to isolate pesticides from low fat food ${ }^{11}$. In fact, in the last years, SFE is being used as sample preparation method for multiresidue analysis, for example Valverde et $a l .^{12}$ developed a method to analyze 22 pesticides by GCECD/NPD from rice, wild rice and wheat; in their work, $\mathrm{CO}_{2}$ at $20 \mathrm{MPa}$ and $50{ }^{\circ} \mathrm{C}$ was used in combination with methanol as modifier and results were compared with classical 250 extraction using ethyl acetate as extracting solvent, providing the use of SFE with better results than the conventional approach.

Beside pesticides, some other examples of pollutants that can be extracted in foods and other matrices by SFE are PAHs (Polycyclic Aromatic Hydrocarbons) ${ }^{13}$, halogenated dioxins and biphenyls (PCBs) ${ }^{14,15}$ veterinary drugs ${ }^{16,17}$, etc. An interesting application by

255 Choi et al. $^{17}$ has been the extraction of polar and nonpolar fluoroquinolone antibiotics (enrofloxacin, danofloxacin, and ciprofloxacin) in pork by using $\mathrm{Na}_{4}$ EDTA and sea sand in combination with $\mathrm{CO}_{2}$ at $80{ }^{\circ} \mathrm{C}, 30 \mathrm{MPa}$ and $30 \%$ methanol. The interest in controlling the presence of drug residues in livestock products has raised important public health concerns 
(related to toxic effects, development of resistant strains of bacteria, allergic

260 hypersensitivity reactions, etc.) as well as environmental and industrial (cheese or yoghurt production, etc.) problems.

Removal of naturally occurring toxins: several kinds of toxins can be present in food depending on their origin, namely, mycotoxins, algal toxins or plant toxins. In many cases, these toxins are large polar compounds that cannot be extracted by supercritical fluids, but

265 not always. Some examples are the isolation of toxins from Acorus calamus $^{18}$ or from Podophyllum hexandrum rizhomes ${ }^{19}$, where SFE provided much higher recoveries of some toxins, using neat $\mathrm{CO}_{2}$, than conventional Soxhlet.

Removal of unwanted compounds from food matrices: sometimes compounds found naturally in foods are not toxic but they decrease the overall quality of the food; this is the

270 case of the presence of free fatty acids in several oils such as olive oil ${ }^{20}$, soybean oil ${ }^{21}$, yuzu $\mathrm{oil}^{22}$ which are related to the quality of the fruits prior to oil extraction. Deacidification processes can be conducted by countercurrent SFE with advantages compared to conventional chemical processes providing two fractions, the deacidified oil in the raffinate fraction, and free fatty acids and volatile compounds in the separators.

275 Removal and use of both fractions: the very first example of this process is the removal of caffeine from coffee ${ }^{9}$, in this example both fractions are used: decaffeinated coffee and caffeine. Nowadays not only coffee can be used as source of caffeine, but also tea ${ }^{23}$ and other herbs like mate herb ${ }^{24}$. In both cases, mild pressures combined with temperatures close to $60^{\circ} \mathrm{C}$ must be used to increase extraction ratio. Another example is the removal of 280 odorant volatile compounds from winemaking inactive dry yeast preparation ${ }^{25}$. Inactive dry yeasts are used as supplement to enhance wine fermentation, but during the inactivation of 
yeast several odorant compounds are synthesized; the use of $20 \mathrm{MPa}, 60^{\circ} \mathrm{C}$ and ethanol as co-solvent provided an inactive dry yeast preparation free of odorant compounds and an extract rich in "toasted" flavor that could be used in bakery products.

285 Another example using liquid matrices together with countercurrent extraction is the fractionation of wine to obtain three valuable fractions: dealcoholized wine, ethanol and wine. First, the recovery of aroma from wine was attained in a countercurrent packed column (white and red wines were investigated) using very low $\mathrm{CO}_{2} /$ wine ratios. Then, the aroma-free wine recovered from the bottom of the extraction column was dealcoholized by applying different extraction conditions. The results obtained from these studies permit the design of a two-step countercurrent $\mathrm{CO}_{2}$ extraction process at $9.5 \mathrm{MPa}$ and $40^{\circ} \mathrm{C}$, in which the different $\mathrm{CO}_{2}$ /wine ratios employed in each step lead to the recovery of aroma or the removal of ethanol. One example of countercurrent extraction apparatus can be seen in Figure 3.

295

A similar approach has been also used for the fractionation of essential oils ${ }^{26}$, recovery of used oils ${ }^{27}$, extraction of tocopherols from oil production byproducts ${ }^{28}$ or recovery of alkoxyglycerols from shark liver oil ${ }^{29}$ 


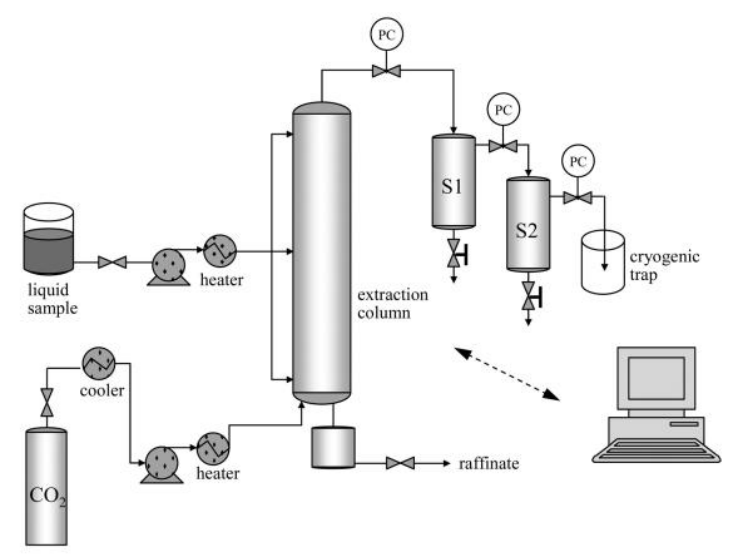

Figure 3. Experimental CC-SFE device. Reprinted with permission from Vázquez, L.;

Fornari, T.; Señoráns, F. J.; Reglero, G.; Torres, C. F. Supercritical Carbon Dioxide Fractionation of Nonesterified Alkoxyglycerols Obtained from Shark Liver Oil. J. Agric. Food Chem. 2008, 56 (3), 1078-1083. Copyrights (2008) American Chemical Society.

\subsubsection{From plants}

One of the most widely studied applications of the use of supercritical fluids is obtaining functional food ingredient from plants. Notably, there is an important increase in the number of published works in the last decade about the use of supercritical fluids for the 315 recovery of bioactive compounds, mainly with antioxidant activity. Aromatic plants, fruits, legumes and seeds have been used as source of natural antioxidant compounds. Table 2 summarizes the more remarkable studies published in the last five years (2009-13) for the SFE of bioactive compounds from plants. 
Published in Supercritical Fluid Extraction (2014). In: Reedijk, J. (Ed.) Elsevier Reference Module in Chemistry, Molecular Sciences andChemical Engineering. Waltham, MA:

Elsevier. 30-Jun-14 doi: 10.1016/B978-0-12-409547-2.10753-X.

320 An important application is the SFE of essential oil from medicinal herbs. Essential oils have been traditionally employed in the manufacture of foodstuffs, cosmetics, cleaning products, herbicides, fragrances, and insecticides. Depending on the location and the community knowledge, several of these plants have been used in traditional medicine as diuretics, expectorants, digestives, among others uses ${ }^{30,31}$. 
Published in Supercritical Fluid Extraction (2014). In: Reedijk, J. (Ed.) Elsevier Reference Module in Chemistry, Molecular Sciences and Chemical Engineering. Waltham, MA: Elsevier. 30-Jun-14 doi: 10.1016/B978-0-12-409547-2.10753-X.

Table 2. Remarkable recent published works (2009-2013) dealing with the use of SFE for the extraction of bioactive components from plants.

\begin{tabular}{|c|c|c|c|c|c|c|}
\hline \multirow[b]{2}{*}{ Source } & \multirow{2}{*}{$\begin{array}{l}\text { Bioactive } \\
\text { compound of } \\
\text { interest }\end{array}$} & \multirow{2}{*}{$\begin{array}{l}\text { Related functional } \\
\text { bioactivities }\end{array}$} & \multicolumn{3}{|c|}{ Extraction conditions } & \multirow[b]{2}{*}{ Reference } \\
\hline & & & Solvent & $\mathbf{P}(\mathbf{M P a}) / \mathbf{T}\left({ }^{\circ} \mathbf{C}\right)$ & $\begin{array}{l}\text { Extraction time } \\
\text { (min) / Mode }\end{array}$ & \\
\hline Amaranth seeds & $\begin{array}{l}\text { Squalene, } \\
\text { tocopherols }\end{array}$ & Antioxidant activity & $\mathrm{CO}_{2}+$ ethanol & $65 / 40$ & 180/dynamic & (32) \\
\hline $\begin{array}{c}\text { Braccharis } \\
\text { dracunculifolia leaves }\end{array}$ & Artepillin C & Antioxidant activity & $\mathrm{CO}_{2}$ & $40 / 60$ & $\begin{array}{l}20+260 / \text { static }+ \\
\text { dynamic }\end{array}$ & $(33)$ \\
\hline Camellia sinensis & $\begin{array}{l}\text { Fatty acids and } \\
\text { antioxidants }\end{array}$ & Antioxidant activity & $\mathrm{CO}_{2}$ & $32 / 45$ & 90/static & (34) \\
\hline $\begin{array}{c}\text { Ginger } \\
\text { (Zingiber officinale R.) }\end{array}$ & $\begin{array}{l}\text { Phenolic } \\
\text { compounds }\end{array}$ & Antioxidant activity & $\begin{array}{l}\mathrm{CO}_{2} \\
\text { Propane }\end{array}$ & $\begin{array}{l}\mathrm{CO}_{2}: 25 / 60 \\
\text { Propane: } 10 / 60\end{array}$ & 180/dynamic & $(35)$ \\
\hline Green Tea Leaves & Caffeine & Stimulant & $\mathrm{CO}_{2}+$ ethanol & $23 / 65$ & 120/dynamic & (36) \\
\hline Hemerocallis disticha & Lutein, zeaxanthin & Antioxidant activity & $\mathrm{CO}_{2}$ & $60 / 80$ & $\begin{array}{l}30+30 / \text { static }+ \\
\text { dynamic }\end{array}$ & (37) \\
\hline Magnolia officinalis & $\begin{array}{l}\text { Honokiol and } \\
\text { Magnolo }\end{array}$ & $\begin{array}{l}\text { antioxidant, anti- } \\
\text { inflammatory } \\
\text { activities }\end{array}$ & $\mathrm{CO}_{2}$ & $40 / 80$ & $\begin{array}{l}60+40 / \text { static }+ \\
\text { dynamic } /\end{array}$ & (38) \\
\hline Mangifera indica leaves & $\begin{array}{l}\text { Phenolic } \\
\text { compound }\end{array}$ & Antioxidant activity & $\mathrm{CO}_{2}+$ ethanol & $40 / 55$ & 180/dynamic & (39) \\
\hline Mitragyna speciosa & Alkaloids & NI & $\mathrm{CO}_{2}+$ ethanol & $30 / 65$ & 45/dynamic & (40) \\
\hline Olive leaves & $\begin{array}{l}\text { Phenolic } \\
\text { compounds }\end{array}$ & Cytotoxic activity & $\mathrm{CO}_{2}+$ ethanol & $15 / 40$ & 120/dynamic & $(41)$ \\
\hline $\begin{array}{l}\text { Oregano Leaves } \\
\text { (Origanum vulgare) }\end{array}$ & Essential oil & $\begin{array}{l}\text { Anti-inflammatory } \\
\text { activity }\end{array}$ & $\mathrm{CO}_{2}$ & $30 / 40$ & NI/dynamic & $(42)$ \\
\hline Persea indica & $\begin{array}{l}\text { Diterpene } \\
\text { ryanodanes }\end{array}$ & $\begin{array}{l}\text { Insecticidal } \\
\text { antifeedant activity }\end{array}$ & $\mathrm{CO}_{2}$ & $20 / 50$ & 660/dynamic & $(43)$ \\
\hline $\begin{array}{c}\text { Pumpkin } \\
\text { (Cucurbita maxima) }\end{array}$ & Carotenoids & Antioxidant activity & $\mathrm{CO}_{2}+$ ethanol & $25 / 80$ & 60/dynamic & $(44)$ \\
\hline $\begin{array}{c}\text { Rosemary } \\
\text { (Rosmarinus officinalis) }\end{array}$ & $\begin{array}{l}\text { Carnosic acid, } \\
\text { Carnosol, } \\
\text { Rosmarinic acid }\end{array}$ & $\begin{array}{l}\text { Antiproliferative } \\
\text { colon cancer cells } \\
\text { activity }\end{array}$ & $\mathrm{CO}_{2}+$ ethanol & $150 / 40$ & 300/dynamic & $(45)$ \\
\hline Rosemary & Phenolic & Antioxidant activity & $\mathrm{CO}_{2}$ & $30 / 40$ & 300/dynamic & $(46)$ \\
\hline
\end{tabular}


Published in Supercritical Fluid Extraction (2014). In: Reedijk, J. (Ed.) Elsevier Reference Module in Chemistry, Molecular Sciences and Chemical Engineering. Waltham, MA: Elsevier. 30-Jun-14 doi: 10.1016/B978-0-12-409547-2.10753-X.

\begin{tabular}{|c|c|c|c|c|c|c|}
\hline (Rosmarinus officinalis) & compounds & & & & & \\
\hline $\begin{array}{c}\text { Rosemary } \\
\text { (Rosmarinus officinalis) }\end{array}$ & $\begin{array}{l}\text { Volatile } \\
\text { compounds, } \\
\text { carnosic and } \\
\text { carnosol }\end{array}$ & $\begin{array}{l}\text { Antioxidant activity } \\
\text { for use in edible } \\
\text { oils }\end{array}$ & $\mathrm{CO}_{2}+$ ethanol & $15 / 40$ & 180/dynamic & (47) \\
\hline $\begin{array}{l}\text { Rosemary + spinach } \\
\text { leaves }(50 \%)\end{array}$ & $\begin{array}{l}\text { Phenolic diterpenes } \\
\text { and carotenoids }\end{array}$ & Antioxidant activity & $\mathrm{CO}_{2}$ & $30 / 40$ & 300/dynamic & (48) \\
\hline Satureja hortensis L & $\begin{array}{l}\text { Phenolic } \\
\text { compounds }\end{array}$ & Antioxidant activity & $\mathrm{CO}_{2}+$ ethanol & $45 / 40$ & 60/dynamic & (49) \\
\hline $\begin{array}{c}\text { Spearmint } \\
\text { (Mentha spicata L.) }\end{array}$ & Essential oil & Antioxidant activity & $\mathrm{CO}_{2}$ & $9 / 35$ & 30/static & (50) \\
\hline $\begin{array}{c}\text { Strawberry } \\
\text { (Arbutus unedo) }\end{array}$ & Total phenolics & Antioxidant activity & $\mathrm{CO}_{2}+$ ethanol & $60 / 48$ & 60/dynamic & (51) \\
\hline $\begin{array}{c}\text { Thyme } \\
\text { (Thymus vulgaris, } \\
\text { vulgaris, Thymus } \\
\text { hyemalis, Thymus zygis) }\end{array}$ & $\begin{array}{l}\text { Thymol, carvacrol, } \\
\text { borneol, linalool }\end{array}$ & Antiviral activity & $\mathrm{CO}_{2}$ & $30 / 40$ & $480 \mathrm{~min} /$ dynamic & (52) \\
\hline Usnea arbata $L$. & Usnic acid & $\begin{array}{l}\text { Antibacterial } \\
\text { activity }\end{array}$ & $\mathrm{CO}_{2}$ & $30 / 40$ & NI/dynamic & (53) \\
\hline
\end{tabular}

NI: Not indicated 
Essential oils have a complex composition containing a few dozen to several hundreds of components, especially hydrocarbons (terpenes and sesquiterpenes), and oxygenates

335 (alcohols, aldehydes, ketones, acids, phenols, oxides, lactones, acetals, ethers and esters). Besides their fragrance, the mixture of compounds confers several bioactivities (e.g., antimicrobial and antioxidant). Among the most well-known advantages of SFE towards the extraction of essential oils is the use of low temperatures that preserve the integrity of the sample. Recently, Fornari et al. ${ }^{31}$ reviewed the advances in SFE of essential oils and

340 accomplished an analysis of the effect of matrix and process conditions.

As can be observed from the information presented in Table 2, the bioactives extracted belong to a wide range of compound classes, from polar phenolic compounds to carotenoids, alkaloids, and other pigments and essential oils. As mentioned, in order to extend the polarity range of compounds extracted, ethanol and methanol have been used as

345 modifiers. Usually, quantities of up to $20 \%^{54-49}$ have been employed, although percentages as low as $2-5 \%$ have shown to be useful to extract, for instance, polyphenols and terpenoids 55,32 .

Other less polar bioactive compounds can be potentially recovered by using small amounts of modifiers or even using pure $\mathrm{CO}_{2}$ at higher pressures. Compounds such as carotenoids, 350 with low polarity, generally need to be extracted using high pressures due to their low solubility in $\mathrm{CO}_{2}$. These components are basically interesting by their antioxidant activities and coloring properties at the same time. Results of the study of SFE of carotenoids from Pumkim (Cucurbita maxima) ${ }^{56}$ showed that the total amount of carotenoids extracted increased by increasing pressure from 25 to $35 \mathrm{MPa}$ and temperature from 40 to $70{ }^{\circ} \mathrm{C}$. The 355 highest pressure tested (35 MPa) presented the highest yield $(109.6 \mathrm{mg} / \mathrm{g})$, with a $73.7 \%$ 
recovery. In fact, $60 \mathrm{MPa}$ of pressure was employed for the extraction of lutein and zeaxanthin from Hemerocallis disticha. Also, the addition of a co-solvent to $\mathrm{SC}-\mathrm{CO}_{2}$ was proven to improve the extraction efficiency ${ }^{37}$. Although so far the antioxidant activity is the most studied feature of the extracts obtained by supercritical fluids, other biological activities such as anti-inflammatory, antiviral, antibacterial, cytotoxicity and antiproliferative activity against cancer cells are started to be explored ${ }^{38-53}$. Santoyo et al ${ }^{52}$ evaluated the antiviral properties of supercritical $\mathrm{CO}_{2}$ extracts obtained from thyme species (Thymus vulgaris, Thymus hyemalis and Thymus zygis) against the herpes simplex virus type 1 (HSV-1) at different stages during virus infection. Results indicated that when cells were pre-treated with the thyme extracts, an important reduction of virus infectivity was achieved; being T. zygis extract more effective than the other thyme species. Meanwhile, Valdes et $a l .{ }^{45}$, studied the effect of rosemary extracts rich on polyphenols (rosmarinic acid, carnosol, carnosic acid) obtained using SFE $\left(15 \mathrm{MPa}, 40^{\circ} \mathrm{C}, 7 \%\right.$ ethanol as modifier) on the gene expression of human SW480 and HT29 colon cancer cells. This study showed that rosemary extracts, more specifically, carnosol/carnosic acid-enriched extracts, showed the strongest effect on the proliferation of both cell lines.

Considering the great variations among bioactive compounds and the huge number of plant species, recently Azmir et al. ${ }^{30}$ adapted from Farnsworth et $a l .{ }^{57}$, a strategy to build up a standard and integrated approach to screen out these compounds with potential benefits for

375 human health. Selection of plant species, evaluation of toxicity, preparation of sample (extraction) and elemental analysis, biological testing, isolation of active compounds and in-vivo analysis are among the steps proposed before marketing the bioactive compounds. Extraction step is critical and a large number of factors have to be properly adjusted in 
order to optimize the process; as mentioned above, the use of experimental designs is of great help in order to minimize the number of experiments needed to determine the optimum extraction conditions. Taguchi, Box-Behnken or central composite experimental designs have been used, among others, for the optimization of response variables involved in the SFE extraction of bioactives from plants ${ }^{58}$. Ramandi et al. ${ }^{59}$ applied a full factorial design for screening the extraction of fatty acids from Borago officinalis L. flowers before optimization using a central composite design. Temperature, pressure, volume of modifier and static extraction time were selected as factors to study their influence on the yield of the extracted oil. Caldera et al. ${ }^{60}$ optimized the SFE of antioxidants (carnosol and carnosic acid) from rosemary (Rosmarinus officinalis L.). $2^{3}$ full factorial design was used to select important variables before optimization of the selected factors by Box-Behnken design.

390 Three factors (temperature, pressure and static extraction time) were studied in this experiment. Extraction pressure, dynamic extraction time as well as modifier volume were the factors studied to maximize the recovery of essential oils from Myrtus comunis leaves ${ }^{61}$ whereas extraction pressure, temperature, and time were the parameters selected in the extraction of Garcinia mangostana ${ }^{62}$. In this latter case, total extraction yield and radical scavenging activity of the extracts were chosen as response variables and the composition and amount of co-solvent used as modifier were kept constant.

\subsubsection{From marine products}

The high biodiversity of the marine environments makes the ocean an extraordinary source of high-value compounds that can be obtained from algae, microalgae, and other marinerelated organisms such as crustaceans, fish, and their by-products ${ }^{63,64}$. Table 3 summarizes 
the most relevant literature recently published (from 2009 to 2013) dealing with the recovery of valuable compounds from marine sources using SFE.

Marine sources, especially fish oil and fish by-products, provide the major natural dietary

405 source of $\omega-3$ PUFAs (polyunsaturated fatty acids), mainly EPA (eicosapentaenoic acid) and DHA (docosahexaenoic acid), which have been associated to a lower incidence of cardiovascular diseases due to their potential biological properties, such as antiinflammatory, antithrombotic and antiarrhythm ${ }^{65}$, 66. Recently, using a fish oil (Pseudoplatystoma corruscans) with low $\omega-3$ fatty acids content (10\%), Lopes et al. ${ }^{67}$

410 studied the possibility, under different temperatures and pressures, of fractionating the TAGs with respect to EPA and DHA and demonstrate that the fractionation is improved by using fish oil with lower $\omega-3$ fatty acids content as the basis.

The applicability of SFE technology to add value to fish industry waste products has been also demonstrated by using different fish by-products and some marine invertebrate as raw 415 materials to obtain $\omega-3$ PUFAs. Yamaguchi et al. ${ }^{68}$ reported for the first time the application of SFE to crustacean waste. These authors extracted mainly triglycerides from the Antarctic Krill and analyzed the effects of temperature $\left(40-80^{\circ} \mathrm{C}\right)$ and pressure $(25.5$ $\mathrm{MPa}$ ) on oil extraction with $\mathrm{SC}-\mathrm{CO}_{2}$. Later, Hardardottir and Kinsella ${ }^{69}$ studied the extraction of lipids from rainbow trout in a range of pressures and temperatures of 13.8 34.5 $\mathrm{MPa}$ and $40-50^{\circ} \mathrm{C}$, respectively. Also, the addition of $10 \%$ ethanol as co-solvent was

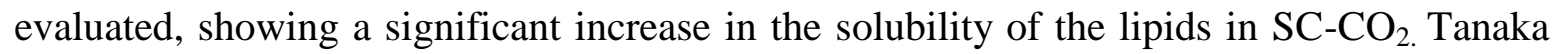
and $\mathrm{Ohkubo}^{70}$ reported data from SC-CO ${ }_{2}$ extraction of carotenoids and lipids from salmon roe. These researchers used pressures and temperatures ranging from 9.8-31.4 MPa and 40$80^{\circ} \mathrm{C}$, respectively. 
Published in Supercritical Fluid Extraction (2014). In: Reedijk, J. (Ed.) Elsevier Reference Module in Chemistry, Molecular Sciences and Chemical Engineering. Waltham, MA: Elsevier. 30-Jun-14 doi: 10.1016/B978-0-12-409547-2.10753-X.

Table 3. Remarkable recent published works (2009-2013) dealing with the use of SFE for the extraction of bioactive components from marine products and byproducts.

\begin{tabular}{|c|c|c|c|c|c|c|}
\hline \multirow[b]{2}{*}{ Marine Source } & \multirow{2}{*}{$\begin{array}{c}\text { Bioactive } \\
\text { compound of } \\
\text { interest }\end{array}$} & \multirow{2}{*}{$\begin{array}{l}\text { Related functional } \\
\text { bioactivities }\end{array}$} & \multicolumn{3}{|c|}{ Extraction conditions } & \multirow[b]{2}{*}{ Reference } \\
\hline & & & Solvent & $\mathbf{P}(\mathbf{M P a}) / \mathbf{T}\left({ }^{\circ} \mathbf{C}\right)$ & $\begin{array}{c}\text { Extraction time } \\
(\text { min) / Mode }\end{array}$ & \\
\hline $\begin{array}{l}\text { Arthrospira platensis } \\
\text { (Spirulina platensis) }\end{array}$ & $\begin{array}{c}\text { Fatty acids, } \\
\gamma \text {-linolenic }\end{array}$ & $\begin{array}{l}\text { Anti-inflammatory, } \\
\text { reduce risk of certain } \\
\text { cardiovascular } \\
\text { diseases }\end{array}$ & $\begin{array}{l}\mathrm{CO}_{2} \text { :ethanol } \\
\quad(1: 1)\end{array}$ & $30 / 40$ & 90/ dynamic & (71) \\
\hline $\begin{array}{l}\text { Brazilian red-spotted } \\
\text { shrimp waste (shell } \\
\text { and tail) }\end{array}$ & $\begin{array}{l}\omega \text {-3 PUFAs, } \\
\text { Astaxanthin }\end{array}$ & $\begin{array}{l}\text { Antioxidant activity, } \\
\text { Anti-inflammatory, } \\
\text { reduce risk of certain } \\
\text { cardiovascular } \\
\text { diseases }\end{array}$ & $\mathrm{CO}_{2}+$ ethanol & $30 / 50$ & $\begin{array}{c}20+100 / \text { static }+ \\
\text { dynamic }\end{array}$ & (72) \\
\hline $\begin{array}{l}\text { Brazilian red-spotted } \\
\text { shrimp waste (heads, } \\
\text { shell and tail) }\end{array}$ & $\begin{array}{l}\omega-3 \text { PUFAs, } \\
\text { Astaxanthin }\end{array}$ & $\begin{array}{l}\text { Antioxidant activity, } \\
\text { Anti-inflammatory, } \\
\text { reduce risk of certain } \\
\text { cardiovascular } \\
\text { diseases }\end{array}$ & $\mathrm{CO}_{2}$ & $40 / 60$ & $\begin{array}{c}20+200 / \text { static }+ \\
\text { dynamic }\end{array}$ & (73) \\
\hline Chlorella vulgaris & Lutein & Antioxidant activity & $\mathrm{CO}_{2}+$ ethanol & $40 / 40$ & 45/dynamic & (74) \\
\hline Chlorella vulgaris $\mathrm{C}-\mathrm{C}$ & $\begin{array}{l}\text { Polyphenols and } \\
\text { Flavonoids }\end{array}$ & $\begin{array}{l}\text { Antioxidant and anti- } \\
\text { cancer activity }\end{array}$ & $\mathrm{CO}_{2}+$ ethanol & $31 / 50$ & 20/static & (75) \\
\hline $\begin{array}{l}\text { Fish by-products (off } \\
\text { cuts from hake, orange } \\
\text { roughy and salmon, } \\
\text { and livers from jumbo } \\
\text { squid) }\end{array}$ & $\omega-3$ PUFAs, & $\begin{array}{l}\text { anti-inflammatory, } \\
\text { reduce risk of certain } \\
\text { cardiovascular } \\
\text { diseases }\end{array}$ & $\mathrm{CO}_{2}$ & $25 / 40$ & 90/dynamic & (63) \\
\hline $\begin{array}{c}\text { Fish by-product } \\
\text { (Indian mackerel skin) }\end{array}$ & $\omega-3$ PUFAs & $\begin{array}{l}\text { Anti-inflammatory, } \\
\text { reduce risk of certain } \\
\text { cardiovascular } \\
\text { diseases }\end{array}$ & $\mathrm{CO}_{2}$ & $35 / 75$ & $\begin{array}{c}180 / 10 \text { static } \\
\text { cycles of } 18 \mathrm{~min}\end{array}$ & (76) \\
\hline
\end{tabular}


Published in Supercritical Fluid Extraction (2014). In: Reedijk, J. (Ed.) Elsevier Reference Module in Chemistry, Molecular Sciences and Chemical Engineering. Waltham, MA: Elsevier. 30-Jun-14 doi: 10.1016/B978-0-12-409547-2.10753-X.

\begin{tabular}{|c|c|c|c|c|c|c|}
\hline $\begin{array}{c}\text { Fish oil } \\
\text { (Pseudoplatystoma } \\
\text { corruscans) }\end{array}$ & $\omega-3$ PUFAs & $\begin{array}{l}\text { Anti-inflammatory, } \\
\text { reduce risk of certain } \\
\text { cardiovascular } \\
\text { diseases }\end{array}$ & $\mathrm{CO}_{2}$ & $20 / 40$ & $\begin{array}{c}\text { 30/ static + } \\
\text { dynamic }\end{array}$ & (67) \\
\hline $\begin{array}{c}\text { Haematococcus } \\
\text { pluvialis }\end{array}$ & Astaxanthin & $\begin{array}{l}\text { Antioxidant activity } \\
\text { for use in edible oils }\end{array}$ & $\mathrm{CO}_{2}+$ ethanol & $50 / 75$ & $\begin{array}{c}60+150 / \text { static }+ \\
\text { dynamic }\end{array}$ & (77) \\
\hline $\begin{array}{c}\text { Monoraphidium sp. } \\
\text { GK12 }\end{array}$ & Astaxanthin & Antioxidant activity & $\mathrm{CO}_{2}+$ ethanol & $20 / 60$ & 60/static & (78) \\
\hline $\begin{array}{c}\text { Nannochloropsis } \\
\text { oculata }\end{array}$ & Lipids, zeaxanthin & $\begin{array}{l}\text { Anti-inflammatory, } \\
\text { reduce risk of certain } \\
\text { cardiovascular } \\
\text { diseases, Antioxidant } \\
\text { activity }\end{array}$ & $\mathrm{CO}_{2}+$ ethanol & $35 / 50$ & NI/dynamic & (79) \\
\hline $\begin{array}{l}\text { Northern shrimp by- } \\
\text { products (heads, shell } \\
\text { and tail) }\end{array}$ & $\omega-3$ PUFAs & $\begin{array}{l}\text { Anti-inflammatory, } \\
\text { reduce risk of certain } \\
\text { cardiovascular } \\
\text { diseases }\end{array}$ & $\mathrm{CO}_{2}$ & $35 / 40$ & 90/dynamic & $(80)$ \\
\hline Saragssum Muticum & Phorotannins & Antioxidant activity & $\mathrm{CO}_{2}+$ ethanol & $15.2 / 60$ & 90/dynamic & (81) \\
\hline $\begin{array}{l}\text { Scenedesmus } \\
\text { almeriensis }\end{array}$ & $\begin{array}{l}\text { Lutein and } \beta- \\
\text { carotene }\end{array}$ & Antioxidant activity & $\mathrm{CO}_{2}$ & $40 / 60$ & 300/dynamic & $(82)$ \\
\hline $\begin{array}{l}\text { Schizochytrium } \\
\text { limacinum }\end{array}$ & Fatty acids DHA & $\begin{array}{l}\text { Anti-inflammatory, } \\
\text { reduce risk of certain } \\
\text { cardiovascular } \\
\text { diseases }\end{array}$ & $\mathrm{CO}_{2}+$ ethanol & $35 / 40$ & $\begin{array}{c}\text { 30/ Urea } \\
\text { complexation + } \\
\text { static }\end{array}$ & (83) \\
\hline $\begin{array}{c}\text { Striped weakfish } \\
\text { (Cynoscion striatus) } \\
\text { wastes }\end{array}$ & $\begin{array}{c}\text { Polyunsaturated } \\
\text { fatty acids (PUFA) }\end{array}$ & $\begin{array}{l}\text { Anti-inflammatory, } \\
\text { reduce risk of certain } \\
\text { cardiovascular } \\
\text { diseases }\end{array}$ & $\mathrm{CO}_{2}$ & $30 / 60$ & 150/dynamic & (84) \\
\hline
\end{tabular}

NI: Not indicated 
Authors observed that at constant temperature, the oil extraction yield increased with the 430 pressure; the highest oil recovery (about 60\%) was achieved under the maximum conditions tested. In general, they observed that the low molecular weight triglycerides were easily extracted easily at low pressures and triglycerides of high molecular weight were readily extracted at high pressures. Another interesting work recently developed by SánchezCamargo et $a l^{72}$ studied the effect of the addition of ethanol on the extraction yields of 435 lipids and astaxanthin from redspotted shrimp waste (farfantepenaeus paulensis). Results showed that the extraction yields increase considerably with the increase in the amount of ethanol in the solvent mixture, reaching maximum recoveries of $93.8 \%$ and $65.2 \%$ for lipids and astaxanthin, respectively, when employing $15 \%$ ethanol. Besides, increasing the amount of ethanol resulted in increase in the concentration of the $\omega-3$ fatty acids in the 440 lipids of the extract.

Macroalgae, microalgae and cyanobacteria have been also used as natural sources for the extraction of lipids and antioxidants, namely carotenoids, isoflavones, polyphenols, and flavonoids ${ }^{85}$. Due to their polarity, these compounds have been traditionally extracted using organic solvents. However, most of the applications presented in Table 3 employed 445 certain amount of a co-solvent (ethanol or methanol) to modify the polarity of the $\mathrm{SC}-\mathrm{CO}_{2}$. For instance, Wang et al..$^{77}$ extracted carotenoids (astaxanthin) from Haematococcus pluvialis and studied its antioxidant potential in sunflower oil. An increasing co-solvent amount resulted in an improved astaxanthin yield at $40 \mathrm{MPa}$ and $65^{\circ} \mathrm{C}$. Since carotenoids volatility is very low, the use of modifiers is gene rally recommended instead of increasing 450 the pressure above $50 \mathrm{MPa}$. The addition of the extract to sunflower oil showed a significant increase in the oxidation stability of the sample at low temperatures, resulting in 
a higher inhibitory effect on the peroxide formation. On the other hand, the use of high amounts of modifier (up to 50\%) was tested to obtain fractions enriched in $\gamma$-linolenic acid from the cyanobacteria Arthrospira platensis (Spirulina platensis); using $\mathrm{CO}_{2}$-expanded 455 ethanol at $30 \mathrm{MPa}, 40^{\circ} \mathrm{C}$ and a ratio $\mathrm{CO}_{2}$ : ethanol $1: 1$ in the optimum, a recovery up to $35.3 \%$ was achieved ${ }^{71}$.

One recent interesting area of research is the supercritical fluid extraction of phenolic compounds (phenols, flavonoids) from marine sources. For instance, Wang et al. ${ }^{75}$ used SFE to extract the active components (flavonoids as antioxidants) from a novel microalga, ethanol mix as modifier, and ultrasound assisted extraction (UAE) with 50\% aqueous ethanol, and reported that polyphenol and flavonoid content obtained under SFE conditions were 29.1 and 3.7-fold higher than those obtained using UAE, respectively. This resulted in a higher antioxidant activity and better inhibition of lung cancer metastasis.

\subsubsection{From food by-products}

Food industrial processing generates a large quantity and variety of by-products and wastes ranging from manure to packing residuals; this fact has raised important environmental concerns mainly related to their disposal and/or elimination. A strong research has emerged towards the development of suitable alternatives for these by-products, aimed to create high-value products. Their conversion into valuable materials by, for instance, the extraction of high-value compounds can provide enormous benefits from an environmental and economic point of view. SFE has been widely used, among other applications, to add 
value to agricultural and food by-products ${ }^{86-87}$ that have been employed as source of

475 bioactive compounds (Table 4).

The main bioactive compounds extracted by SFE from agricultural and food by-products have been polyphenols and carotenoids with antioxidant properties, but also fatty acids, phytosterols and essential oils. Polyphenols extraction is generally carried out by using ethanol as co-solvent in amounts ranging between 10-20\%, although extraction using up to $48060 \%$ has been reported ${ }^{88}$ Most of the published works about polyphenols extraction measured the efficiency of the extraction of these bioactive compounds using FolinCiocalteu methodology and thus expressing their outcomes as Total Phenolic Content (TPC); however, some studies measure the levels of specific compounds such as resveratrol $^{89}$, kaempferol glycosides ${ }^{88}$ and chlorogenic acid ${ }^{90}$. Recently, olives processing 485 by-products $^{41,91}$, vineyard ${ }^{89,} 92$ and winemaking residues ${ }^{93}$ have been recognized as a potential sources of polyphenols with high antioxidant activity. Peralbo-Molina \& Luque de Castro ${ }^{94}$ reviewed the potential of these residues from the Mediterranean agriculture and agrifood industry.

Regarding carotenoids, lycopene is the most studied pigment and antioxidant extracted from food by-products, it is the most abundant carotenoid in tomatoes, accounting for more than $80 \%$ of the pigments present in fully red ripe fruits ${ }^{95-96}$. SFE extraction of carotenoids has been mainly carried out from tomato by-products (skins, seeds and tomato paste waste), although it has been also extracted from water melon, pink guava, apricot by-products and carrot press cakes ${ }^{95,97}$. Extraction temperature is a critical variable affecting extraction efficiency of $\mathrm{SC}-\mathrm{CO}_{2}$ extractions. 
Published in Supercritical Fluid Extraction (2014). In: Reedijk, J. (Ed.) Elsevier Reference Module in Chemistry, Molecular Sciences and Chemical Engineering. Waltham, MA: Elsevier. 30-Jun-14 doi: 10.1016/B978-0-12-409547-2.10753-X.

Table 4. Remarkable recent published works (2009-2013) dealing with the use of SFE for the extraction of bioactive components from food by-products

\begin{tabular}{|c|c|c|c|c|c|c|}
\hline \multirow[b]{2}{*}{ Food by-product } & \multirow{2}{*}{$\begin{array}{l}\text { Compounds of } \\
\text { interest }\end{array}$} & \multirow{2}{*}{$\begin{array}{l}\text { Related functional } \\
\text { bioactivities }\end{array}$} & \multicolumn{3}{|c|}{ Extraction conditions } & \multirow[b]{2}{*}{ Reference } \\
\hline & & & Solvent & $\mathbf{P}(\mathbf{M P a}) / \mathbf{T}\left({ }^{\circ} \mathbf{C}\right)$ & $\begin{array}{l}\text { Extraction time } \\
(\min ) / \text { Mode }\end{array}$ & \\
\hline Banana peel & $\begin{array}{l}\text { Carotenoids, fatty } \\
\text { acids, phytosterols, } \\
\text { triterpenes }\end{array}$ & NI & $\mathrm{CO}_{2}$ & $30 / 50$ & 220/dynamic & $(98)$ \\
\hline Grape bagasse & Polyphenols & Antioxidant activity & $\mathrm{CO}_{2}+$ ethanol & $35 / 40$ & $\begin{array}{c}10+340 / \text { static } \\
\text { dynamic }\end{array}$ & (93) \\
\hline $\begin{array}{l}\text { Grape by-products } \\
\text { (seed, stem, skin and } \\
\text { pomace) }\end{array}$ & Resveratrol & Antioxidat activity & $\mathrm{CO}_{2}+$ ethanol & $40 / 35$ & 180/dynamic & (89) \\
\hline Grape seed & Proanthocyanidins & Antioxidant activity & $\mathrm{CO} 2+$ ethanol & $30 / 50$ & $60 \mathrm{~min} /$ dynamic & $(92)$ \\
\hline $\begin{array}{c}\text { Guava seeds } \\
\text { (Psidium guajava) }\end{array}$ & $\begin{array}{l}\text { Phenolic } \\
\text { compounds }\end{array}$ & Antioxidant activity & $\mathrm{CO}_{2}+$ ethanol & $30 / 50$ & 30/static x 4 cycles & (99) \\
\hline $\begin{array}{c}\text { Jabuticaba } \\
\text { (Myrciaria cauliflora) }\end{array}$ & $\begin{array}{l}\text { Polyphenols and } \\
\text { antocyanins }\end{array}$ & Antioxidant activity & $\mathrm{CO} 2$ + ethanol & $30 / 60$ & NI/ dynamic & (100) \\
\hline Melon seeds & $\begin{array}{l}\text { Phytosterol- } \\
\text { enriched oil }\end{array}$ & NI & $\mathrm{CO}_{2}$ & $40 / 80$ & $\begin{array}{c}30+180 / \text { static }+ \\
\text { dynamic }\end{array}$ & (101) \\
\hline Olive oil mill waste & $\begin{array}{l}\text { Phenolic } \\
\text { compounds }\end{array}$ & Antioxidant activity & $\mathrm{CO}_{2}$ & $35 / 40$ & 60/dynamic & (91) \\
\hline $\begin{array}{c}\text { Orange (Citrus } \\
\text { sinensis L. Osbeck) } \\
\text { pomace }\end{array}$ & $\begin{array}{l}\text { Flavonoids, } \\
\text { phenolic acids and } \\
\text { terpenes }\end{array}$ & $\begin{array}{l}\text { Antioxidant activity, } \\
\text { Antimicrobial } \\
\text { activity }\end{array}$ & $\mathrm{CO}_{2}+$ ethanol & $30 / 50$ & 300/dynamic & (102) \\
\hline Palm kernel cake & Palm oil & NI & $\mathrm{CO}_{2}$ & $41.36 / 70$ & 60/dynamic & (103) \\
\hline $\begin{array}{l}\text { Peach (Prunus } \\
\text { persica) almond }\end{array}$ & $\begin{array}{l}\text { Oleic and Linoleic } \\
\text { acid }\end{array}$ & $\begin{array}{l}\text { LDL cholesterol } \\
\text { redactor }\end{array}$ & $\mathrm{CO}_{2}+$ ethanol & $30 / 50$ & 150/dynamic & (104) \\
\hline $\begin{array}{l}\text { Red pepper (Capsicum } \\
\text { annum L.) by-products }\end{array}$ & $\begin{array}{l}\text { Vitamin E and } \\
\text { provitamin A }\end{array}$ & $\begin{array}{l}\text { Different protective } \\
\text { effects }\end{array}$ & $\mathrm{CO}_{2}$ & $24 / 60$ & $120 /$ dynamic & (105) \\
\hline
\end{tabular}


Published in Supercritical Fluid Extraction (2014). In: Reedijk, J. (Ed.) Elsevier Reference Module in Chemistry, Molecular Sciences and Chemical Engineering. Waltham, MA: Elsevier. 30-Jun-14 doi: 10.1016/B978-0-12-409547-2.10753-X.

\begin{tabular}{|c|c|c|c|c|c|c|}
\hline $\begin{array}{l}\text { Spent coffee grounds } \\
\text { and coffee husks }\end{array}$ & $\begin{array}{c}\text { Caffeine and } \\
\text { chlorogenic acid }\end{array}$ & Antioxidant activity & $\mathrm{CO}_{2}+$ ethanol & $30 / 60$ & $\begin{array}{l}\text { Spent coffee } \\
\text { grounds: } \\
\text { 270/dynamic } \\
\text { Coffee husks: } \\
\text { 150/dynamic }\end{array}$ & $(90)$ \\
\hline Tea seed cake & $\begin{array}{l}\text { Kaempferol } \\
\text { glycoside }\end{array}$ & Antioxidant activity & $\mathrm{CO}_{2}+$ ethanol & $45 / 80$ & 150/dynamic & $(88)$ \\
\hline $\begin{array}{c}\text { Tea stalk and fiber } \\
\text { wastes }\end{array}$ & Caffeine & Stimulant & $\mathrm{CO}_{2}+$ ethanol & $25 / 65$ & 180/dynamic & $(106)$ \\
\hline Sugarcane residue & $\begin{array}{l}\text { Octacosanol, } \\
\text { phytosterols }\end{array}$ & $\begin{array}{c}\text { Hypocholesterolemic } \\
\text { effect }\end{array}$ & $\mathrm{CO}_{2}$ & $35 / 60$ & 360/dynamic & $(107)$ \\
\hline Tomato juice & Lycopene & Antioxidant activity & $\mathrm{CO}_{2}$ & $35 / 40$ & $\begin{array}{c}5+180 \text { or } 360 / \\
\text { static }+ \text { dynamic }\end{array}$ & (96) \\
\hline Tomato peel and seeds & Lycopene & Antioxidant activity & $\mathrm{CO}_{2}$ & $40 / 90$ & 180 /dynamic & $(108)$ \\
\hline Tomato Skin & Lycopene & Antioxidant activity & $\begin{array}{l}\mathrm{CO}_{2}+\text { ethanol+ } \\
\text { olive oil+ water }\end{array}$ & $35 / 75$ & NI/dynamic & (109) \\
\hline Wheat bran & Alkylresorcinols & Antioxidant activity & $\mathrm{CO}_{2}$ & $40 / 80$ & 215/dynamic & (110) \\
\hline
\end{tabular}


While high temperatures can improve the extraction of some carotenoids, it can also induce thermal degradation or isomerization of the compounds during extraction ${ }^{109}$. As for the pressure, values in the range of 20 to $40 \mathrm{MPa}$ provided the best recoveries of carotenoids such as lycopene and $\beta$-carotene. The interaction between temperature and pressure is certainly important in order to maximize carotenoids' extraction yield when $\mathrm{SC}-\mathrm{CO}_{2}$ is used as solvent; however, some studies affirm that the effects of temperature are more significant compared to pressure, for example, in maximizing lycopene recovery ${ }^{95,108}$. Due

510 to the low solubility of certain carotenoids in $\mathrm{CO}_{2}$, the type of modifier and its percentage in the mix with $\mathrm{CO}_{2}$ is a crucial parameter affecting carotenoids' extraction yield. Ethanol and some edible oils like almond, peanut, hazelnut, olive, and sunflower seed oil have been used as co-solvents ${ }^{95}$. The effect of the addition of ethanol, water and olive oil as different co-solvents on the lycopene extraction yield from tomato skin from a tomato processing

515 plant was investigated by Shi et al. ${ }^{109}$; the recovery of lycopene increased when the cosolvent was increased from $5 \%(\mathrm{w} / \mathrm{w})$ to $15 \%(\mathrm{w} / \mathrm{w})$, in the following order: olive oil $(58.2 \%)>$ ethanol $(51.7 \%)>$ water $(48.8 \%)$.

\subsection{Pharmaceutical}

520 Pharmaceutical industries are facing important challenges nowadays, mainly related to the development of production processes with very low environmental impact; in particular, they are urged to reduce the use of volatile organic compounds in drugs synthesis/manufacturing as well as to avoid residues in the finished product. In general terms, the main use of supercritical fluids in pharmaceutics deals with the extraction of 525 bioactive compounds from a mixture (purification from reactions, quantification of active 
enantiomer, extraction from natural matrices, etc.) or with the extraction of the matrix itself. In this case, crystallization and particle formation have undergone an enormous development in recent years ${ }^{111}$. Other benefits of supercritical fluid technologies, strictly related to the above-mentioned new paradigm in pharmaceutics, are linked to the reduced complexity of the process which stems from a reduction of the number of steps as well as to the improved process understanding and control $^{112}$. Despite all the advantages that supercritical fluids can provide to the pharmaceutical industry, extraction is only a minor field in this area; other uses of supercritical fluids are described for their interest although they are not specifically related to SFE:

535 - Particle generation and co-precipitation: In the pharmaceutical industry, fine particles $(\mu \mathrm{m}$ or $\mathrm{nm})$ with uniform narrow size range are of particular interest. Various supercritical (SCF) processes for particle formation include:

i) Rapid expansion of supercritical solutions (RESS): involves a fast depressurization of saturated supercritical fluid-drug solution through a heated nozzle into a low pressure 540 vessel that produces a rapid nucleation of the substrate in form of very small particles ${ }^{113}$. ii) Supercritical antisolvent (SAS) precipitation: a solution composed of a solute and a solvent is injected into the antisolvent (supercritical fluid). While the solvent and the antisolvent are miscible, the solute is quasi non-soluble in the mixture and consequently the mixture is supersaturated and solute particles precipitate ${ }^{114}$.

545 iii) Particles from Gas Saturated Solutions (PGSS): is a process similar to RESS but in this case the substances are not soluble in the supercritical fluid but they are melted forming a dispersion; then, the Joule-Thomsom effect associated to depressurization cools the dispersion and small particles are obtained ${ }^{115}$. 
iv) Aerosol solvent extraction system (ASES): drug and polymer are dissolved or

550 dispersed in an organic solvent which is sprayed into a supercritical phase; the organic solvent, soluble in the supercritical gas phase, is extracted resulting in the formation of solid microparticles of drug+ polymer $^{116}$.

v) Solution enhanced dispersion by supercritical fluids (SEDS): it allows simultaneous dispersion, solvent extraction and particle formation. The drug solution meets the 555 supercritical carbon dioxide in a coaxial nozzle of the SEDS apparatus, producing a supersaturated solute. The turbulent, high-velocity flow speeds both mixing and particle formation. The supercritical carbon dioxide disperses and mixes the drug solution, acting as an anti-solvent at the same time ${ }^{117}$.

- Co-formulation of drug and excipient is one of the emerging concepts in the

560 pharmaceutical industry, in this case some of the above mentioned techniques are used to prepare formulations with drug and polymer ${ }^{118}$ or drugs into liposomes ${ }^{119}$. Attending to the extraction capabilities of supercritical fluids and its use in the pharmaceutical industry, one of the main areas of interest is in solvent removal. Residual solvent removal by superctitical fluids exploits the great diffusivity of the compressed gas as 565 well as the easy evaporation of organic solvent into the supercritical phase. The efficiency of the process is a function of the solid/solvent and the solvent/supercritical fluid affinity ${ }^{112}$. For example, Kluge et al. ${ }^{120}$ proved that crystallization from oil in water emulsions may be used as a purification step; they used SFE to remove the solvent and control crystallization rate of phenanthrene. In this process solvent is extracted 570 before the onset of crystallization, therefore different methods of solvent extraction, such as dilution with water or SFE, affect the process primarily by providing different initial 
conditions for the crystallization step. SFE processed emulsions showed a low residual solvent content, especially in comparison to simple dilution of the system. This causes a higher supersaturation of the oil phase, thus accelerating the self-nucleation of droplets. Both effects are in good agreement with the observation that smaller particles have been obtained at the higher suspension density (see Figure 4). This process has been named as supercritical fluid extraction of emulsions (SFEE).
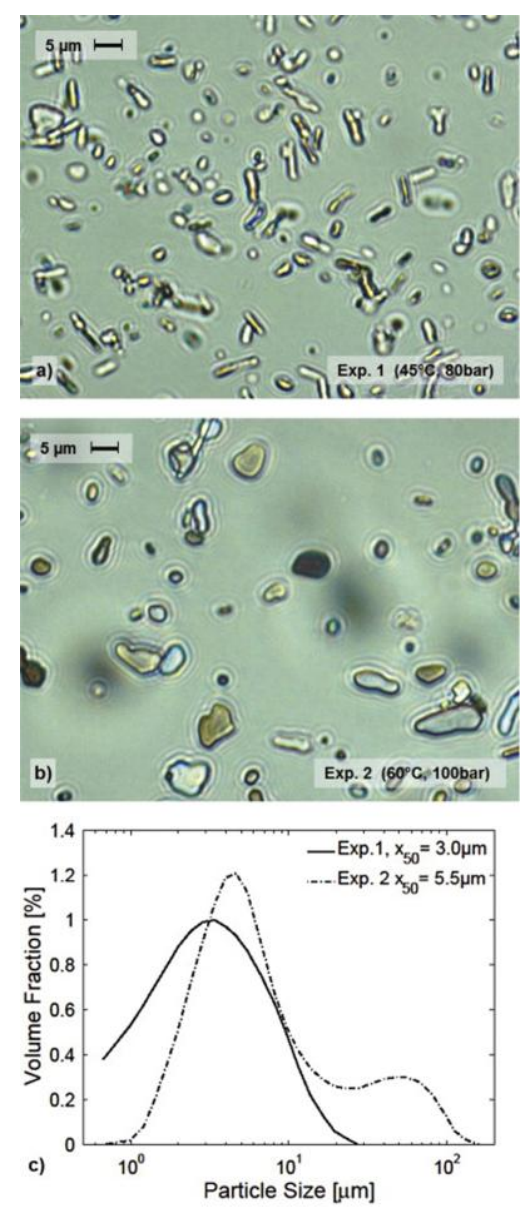

Figure 4. Crystallization upon supercritical fluid extraction of emulsions (SFEE): (a) and (b) Phenanthrene crystals obtained at different operating conditions, (c) corresponding particle size diagram. Reproduced with permission from Kluge et al. ${ }^{109}$. 
SFE can also be used in a combined process of solvent removal and sterilization of drugs.

The process described by Howell et al. ${ }^{121}$ demonstrated that it is possible to inactivate was carried out directly from dispensing vials containing drug, a biological indicator and one sterilant (peracetic acid) and using $\mathrm{SC}-\mathrm{CO}_{2}$ as extracting agent. Recovery of drug and analysis of two drugs treated by the process (acetaminophen and paclitaxel) showed no increase in degradation products. After processing, no residual peracetic acid was detected.

590 The process operates at a temperature of about $37{ }^{\circ} \mathrm{C}\left( \pm 2{ }^{\circ} \mathrm{C}\right)$ and pressure of about $8 \mathrm{MPa}$ and has a full cycle time of less than 90 min. While much remains to be done before this process could be commercially applicable, the procedure is promising, especially for the preparation of drugs that are easily susceptible to hydrolysis in the presence of water.

\subsection{Other applications}

\subsubsection{Heavy metals recovery}

SFE is a promising technique for metal recovery. Chelation combined with solvent extraction is one of the most widely used techniques for separation of metal ions from solid and liquid samples, however these solvent extraction procedures are usually time and labor

600 intensive. In addition, solvent extraction techniques require large amount of organic solvents and often creates environmental problems. In recent years, there has been an increasing interest in extracting metal ions by using SFE. When $\mathrm{CO}_{2}$ is used to extract chelated complexes, $\mathrm{CO}_{2}$ and the chelating agent can be easily separated by simply lowering the pressure of the system ${ }^{122}$. Nejad et al. ${ }^{122}$ optimized the extraction of some 605 lanthanides by SFE using bis(2,4,4-trimethylpentyl)dithiophosphinic acid (Cyanex 301) as 
a chelating agent and tributylphosphate (TBP) as co-extractant. They used a fractional factorial design, $2^{5-1}$ for process optimization considering five experimental factors: amount of Cyanex 301, flow rate, temperature, pressure and amount of TBP, being pressure the most significant factor. Their results showed that $\mathrm{La}^{3+}, \mathrm{Ce}^{3+}$ and $\mathrm{Sm}^{3+}$ ions could be

610 quantitatively extracted from the solid matrix by using the following conditions: amount of Cyanex 301, $0.14 \mathrm{~g}$, flow rate, $4 \mathrm{ml} \mathrm{min-1,} \mathrm{temperature,} 40^{\circ} \mathrm{C}$, pressure, $25 \mathrm{MPa}$, and amount of TBP, $30 \mu 1$.

The possible combination of (food residues + heavy metal) extraction has been demonstrated by Albarelli et al. ${ }^{123}$. These authors analyzed the effects of $\mathrm{SC}-\mathrm{CO}_{2}$ on waste

615 banana peels for copper adsorption. $\mathrm{SC}-\mathrm{CO}_{2}$ was used for antioxidants recovery and in an emerging biomass treatment to increase the efficiency of the subsequent heavy metalremoval step. Adsorption studies showed similar behaviors for fresh and extracted samples, demonstrating that banana peels can successfully be used for the adsorption of copper ions after being subjected to supercritical fluid extraction (SFE) for antioxidant recovery, 620 enabling a promising alternative process chain focused on the integral use of waste banana peels.

\subsubsection{Biopesticides production}

The interest for biopesticides has been growing rapidly since the awareness for 625 sustainability, climate change and organic farming has risen dramatically. Biopesticides, according to the United States Environmental Protection Agency (USEPA) include naturally occurring substances and microorganisms that control pests and pesticidal substances produced by plants containing added genetic material. The production of 
biopesticides is included in the philosophy of Green Chemistry, a current within the

630 Chemistry which seeks safer products with cleaner processes, in this sense supercritical fluids can provide important advantages ${ }^{124}$.

Supercritical fluids are used at different stages and in different approaches in the production of biopesticides. In this review the focus will be on the application of SFE to biopesticides but readers can refer to Martín et al. ${ }^{124}$ for other uses of supercritical fluids for supercritical fluids, pyrethrins and azadirachtins:

- Pyrethrins are the most widely used natural domestic insecticides, extracted from pyrethrum flowers (genre Chrysanthemum) and are comprised mainly by pyrethrin, jasmolin and cinerin. The first application of SFE to obtain pyrethrins was patented in $6401981^{125}$; in general better results are obtained at low temperatures and mild pressures. In a recent study, Cai et al. ${ }^{126}$ compared the results obtained by using hexane and supercritical $\mathrm{CO}_{2}$, their results showed that the main chemical compounds in pyrethrum flower extracts were $\beta$-farnesene, $\beta$-cubebene, ethyl palmitate and ethyl linoleate, besides six pesticidal active compounds of pyrethrins (cinerin I, jasmin I, pyrethrin I,

645 cinerin II, jasmin II and pyrethrin I). The supercritical extract was very similar to the one obtained with n-hexane, still containing waxes and oil, which could be eliminated by cascade depressurization.

- Azadirachtins are tetranortriterpenoids obtained from the tree Azadirachta indica (neem), formed by a group of closely related compounds including azadirachtin, 650 salannin, gemudin and nimbin. They are very active as insecticides but have very low toxicity for vertebrates. In fact, Chen et al. ${ }^{127}$ found that the synergism of azadirachtin, 
oil and other active components in neem SFE extracts could increase the bioactivity against insects. The extraction of one of those azadirachtins, nimbin, was optimized by Zahedi et. $a l^{128}$ who found that optimal conditions to extract nimbin from neem seeds were $40^{\circ} \mathrm{C}$ and $20 \mathrm{MPa}$, with methanol as co-solvent (10\%).

Beside these well-known pesticides, there are several essential oils extracted by supercritical fluids which are being assayed as pesticides. Extracts of thyme (thymus vulgaris) and savory (Satureja hortensis) obtained at $12 \mathrm{MPa}$ and $50^{\circ} \mathrm{C}$ have proven 660 insecticidal activity comparable to traditional pesticides ${ }^{129,130}$. But not only insecticide activity of essential oils obtained by SFE has been assayed, Liang et al. ${ }^{131}$ compared the acaricidal effect of traditional extracts (hydrodistillation and organic solvent extraction) and SFE (18.0 MPa at $40{ }^{\circ} \mathrm{C}$ using ethanol as cosolvent) of Artemisia absinthium. The supercritical extracts exhibited stronger antifeedant effects than the traditional ones (up to 8 665 times more active) with moderate selective phytotoxic effects ${ }^{132}$.

\section{Future trends}

In the present chapter we have tried to present the most recent applications of SFE in different fields, including not only the extraction of valuable compounds from different natural raw materials such as plants, marine products, and agricultural by-products but also new and recent advances in different areas such as food science, pharmaceutical and environmental science. The information is provided as a tool for readers to develop new processes at lab and pilot scale, to discover new ways for sample preparation, to learn how to deal with SFE optimization and how to tune the different parameters involved in the 
675 process and to be able, at the end, to contribute to the development of future emerging technologies able to fulfil the requirements of green chemistry processes. Bearing this in mind, new emerging technologies, for instance the use of supercritical fluids in particle formation, sterilization, heavy metals removal or biopesticides production have been included.

680 Even if SFE is now a real option for product development, mainly those related to new foods, food ingredients or pharmaceutical products, there is still a long way to go to be able to implement and demonstrate the sustainability and eco-friendliness of a particular SFE process; to do so, different tools to evaluate the environmental impact of the different procedures are needed, like those based on life-cycle analysis (LCA). Moreover, more

685 focus is needed in terms of economic considerations of SFE processes at large scale.

Even though in the present chapter applications based on the use of supercritical $\mathrm{CO}_{2}$ (plus some modifiers) are mainly presented for their interest and applicability, the future trends in the SFE field point out to the use of a wider range of experimental conditions (including sub- and supercritical conditions), and a higher number of solvents such as supercritical 690 ethane, near-critical dimethyl ether (DME), gas expanded liquids (GXLs) or combinations of ionic liquids (ILs) and supercritical fluids. Readers are referred to ${ }^{6,133,134}$ for more information on new solvents and approaches.

Finally, it is expected an important development of green processing platforms based on the use of green solvents such as supercritical $\mathrm{CO}_{2}$ and water, multi-unit operations consisting of raw material pre-treatment, reactions, extraction, and biofuel conversion, etc. For a really interesting revision of this important field of research, readers are referred to review of 
Catchpole et al. ${ }^{135}$ where recent developments in integrated processing using supercritical fluids for bioseparations are presented.

Together, all the ideas presented in this chapter and in many other interesting reviews and papers suggested throughout it, can be used towards the real development of process sustainability, providing with new answers to the most challenging demands posted today.

\section{REFERENCES}

1. Cagniard de la Tour, C., Exposé de quelques résultats obtenu par l'action combinée de la chaleur et de la compression sur certains liquides, tels que l'eau, l'alcool, l'éther

705 sulfurique et l'essence de pétrole rectifiée. Annales de Chimie et de Physique 1822, 21, 127-132; Supplément, ibid., 178-182.

2. Cagniard de la Tour, C., Nouvelle note sur les effets qu'on obtient par l'application simultanéede la chaleur et de la compression a certains liquides. Annales de Chimie et de Physique 1823, 22, 410-415.

710 3. Andrews, T., The Bakerian Lecture: On the Continuity of the Gaseous and Liquid States of Matter. Philosophical Transactions of the Royal Society of London 1869, 159, 575-590.

4. Hannay, J. B.; Hogarth, J., On the Solubility of Solids in Gases. Proc. R. Soc. Lond. 1879, 29 324-326.

715 5. Brunner, G., Supercritical fluids: technology and application to food processing. Journal of Food Engineering 2005, 67 (1-2), 21-33.

6. Mendiola, J. A.; Herrero, M.; Castro-Puyana, M.; Ibáñez, E., Supercritical fluid extraction. In Natural products extraction, Rostagno, M. A.; Prado, J. M., Eds. RSC Publishing: Cambridge, 2013; pp 196-230. 
7207 Brunner, G., Gas extraction: an introduction to fundamentals of supercritical fluids and the application to separation processes. Springer-Verlag New York, LLC: 1995.

8. Zosel, K. Process for the separation of mixtures of substances. US Pat 3,969,196, 1976.

9. Zosel, K., Separation with Supercritical Gases: Practical Applications. Angewandte 725 Chemie International Edition in English 1978, 17 (10), 702-709.

10. García-Rodríguez, D.; Carro-Díaz, A. M.; Lorenzo-Ferreira, R. A., Supercritical fluid extraction of polyhalogenated pollutants from aquaculture and marine environmental samples: A review. Journal of Separation Science 2008, 31 (8), 1333-1345.

11. Picó, Y., Recent Advances in Sample Preparation for Pesticide Analysis. In 730 Comprehensive Sampling and Sample Preparation, Pawliszyn, J., Ed. Academic Press: Oxford, 2012; pp 569-590.

12. Valverde, A.; Aguilera, A.; Rodriguez, M.; Brotons, M., Evaluation of a multiresidue method for pesticides in cereals using supercritical fluid extraction and gas chromatographic detection. Journal of Environmental Science and Health, Part B:

735 Pesticides, Food Contaminants, and Agricultural Wastes 2009, 44 (3), 204-213.

13. Bogolte, B. T.; Ehlers, G. A. C.; Braun, R.; Loibner, A. P., Estimation of PAH bioavailability to Lepidium sativum using sequential supercritical fluid extraction - a case study with industrial contaminated soils. European Journal of Soil Biology 2007, 43 (4), $242-250$.

740 14. Kawashima, A.; Watanabe, S.; Iwakiri, R.; Honda, K., Removal of dioxins and dioxin-like $\mathrm{PCB}$ from fish oil by countercurrent supercritical $\mathrm{CO}_{2}$ extraction and activated carbon treatment. Chemosphere 2009, 75 (6), 788-794. 
15. Rodil, R.; Carro, A. M.; Lorenzo, R. A.; Cela, R., Multicriteria optimisation of a simultaneous supercritical fluid extraction and clean-up procedure for the determination of persistent organohalogenated pollutants in aquaculture samples. Chemosphere 2007, 67 (7), 1453-1462.

16. Mahugo-Santana, C.; Sosa-Ferrera, Z.; Torres-Padrón, M. E.; Santana-Rodríguez, J. J., Analytical methodologies for the determination of nitroimidazole residues in biological and environmental liquid samples: A review. Analytica Chimica Acta 2010, 665 (2), 113122.

17. Choi, J.-H.; Mamun, M. I. R.; El-Aty, A. M. A.; Kim, K. T.; Koh, H.-B.; Shin, H.C.; Kim, J.-S.; Lee, K. B.; Shim, J.-H., Inert matrix and Na4EDTA improve the supercritical fluid extraction efficiency of fluoroquinolones for HPLC determination in pig tissues. Talanta 2009, 78 (2), 348-357.

755 18. Yao, Y.; Cai, W.; Yang, C.; Hua, H., Supercritical fluid $\mathrm{CO}_{2}$ extraction of Acorus calamus L. (Arales: Araceae) and its contact toxicity to Sitophilus zeamais Motschusky (Coleoptera: Curculionidae). Natural Product Research 2011, 26 (16), 1498-1503.

19. Gupta, D. K.; Verma, M. K.; Lal, S.; Anand, R.; Khajuria, R. K.; Kitchlu, S.; Koul, S., Extraction studies of Podophyllum hexandrum using conventional and nonconventional methods by HPLC-UV-DAD. Journal of Liquid Chromatography \& Related Technologies 2013, 37 (2), 259-273.

20. Vázquez, L.; Hurtado-Benavides, A. M.; Reglero, G.; Fornari, T.; Ibáñez, E.; Señoráns, F. J., Deacidification of olive oil by countercurrent supercritical carbon dioxide extraction: Experimental and thermodynamic modeling. Journal of Food Engineering 765 2009, $90(4), 463-470$.

21. Goyal, G.; Dwivedi, A. K., Decolourization and deodourization of soyabean oil : A review. Journal of Industrial Pollution Control Paper 2013, 29 (1), 103-110. 
22. Terada, A.; Kitajima, N.; Machmudah, S.; Tanaka, M.; Sasaki, M.; Goto, M., Coldpressed yuzu oil fractionation using countercurrent supercritical $\mathrm{CO}_{2}$ extraction column. Separation and Purification Technology 2010, 71 (1), 107-113.

23. İçen, H.; Gürü, M., Extraction of caffeine from tea stalk and fiber wastes using supercritical carbon dioxide. The Journal of Supercritical Fluids 2009, 50 (3), 225-228.

24. Cassel, E.; Vargas, R. M. F.; Brun, G. W.; Almeida, D. E.; Cogoi, L.; Ferraro, G.; Filip, R., Supercritical fluid extraction of alkaloids from Ilex paraguariensis St. Hil. 775 Journal of Food Engineering 2010, 100 (4), 656-661.

25. Pozo-Bayón, M. a. A. n.; Andújar-Ortiz, I.; Mendiola, J. A.; Ibáñez, E.; MorenoArribas, M. V., Application of Supercritical $\mathrm{CO}_{2}$ Extraction for the Elimination of Odorant Volatile Compounds from Winemaking Inactive Dry Yeast Preparation. Journal of Agricultural and Food Chemistry 2010, 58 (6), 3772-3778.

780 26. Gañán, N.; Brignole, E. A., Supercritical carbon dioxide fractionation of T. minuta and S. officinalis essential oils: Experiments and process analysis. The Journal of Supercritical Fluids 2013, 78 (0), 12-20.

27. Rincón, J.; Martínez, F.; Rodríguez, L.; Ancillo, V., Recovery of triglycerides from used frying oil by extraction with liquid and supercritical ethane. The Journal of 785 Supercritical Fluids 2011, 56 (1), 72-79.

28. Torres, C. F.; Fornari, T.; Torrelo, G.; Señoráns, F. J.; Reglero, G., Production of phytosterol esters from soybean oil deodorizer distillates. European Journal of Lipid Science and Technology 2009, 111 (5), 459-463.

29. Vázquez, L.; Fornari, T.; Señoráns, F. J.; Reglero, G.; Torres, C. F., Supercritical 790 Carbon Dioxide Fractionation of Nonesterified Alkoxyglycerols Obtained from Shark Liver Oil. Journal of Agricultural and Food Chemistry 2008, 56 (3), 1078-1083. 
30. Azmir, J.; Zaidul, I. S. M.; Rahman, M. M.; Sharif, K. M.; Mohamed, A.; Sahena, F.; Jahurul, M. H. A.; Ghafoor, K.; Norulaini, N. A. N.; Omar, A. K. M., Techniques for extraction of bioactive compounds from plant materials: A review. Journal of Food Engineering 2013, 117 (4), 426-436.

31. Fornari, T.; Vicente, G.; Vázquez, E.; García-Risco, M. R.; Reglero, G., Isolation of essential oil from different plants and herbs by supercritical fluid extraction. Journal of Chromatography A 2012, 1250, 34-48.

32. Kraujalis, P.; Venskutonis, P. R., Supercritical carbon dioxide extraction of 800 squalene and tocopherols from amaranth and assessment of extracts antioxidant activity. The Journal of Supercritical Fluids 2013, 80, 78-85.

33. Martinez-Correa, H. A.; Cabral, F. A.; Magalhães, P. M.; Queiroga, C. L.; Godoy, A. T.; Sánchez-Camargo, A. P.; Paviani, L. C., Extracts from the leaves of Baccharis dracunculifolia obtained by a combination of extraction processes with supercritical $\mathrm{CO}_{2}$, 805 ethanol and water. The Journal of Supercritical Fluids 2012, 63, 31-39.

34. Wang, Y.; Sun, D.; Chen, H.; Qian, L.; Xu, P., Fatty Acid Composition and Antioxidant Activity of Tea (Camellia sinensis L.) Seed Oil Extracted by Optimized Supercritical Carbon Dioxide. International Journal of Molecular Sciences 2011, 12 (12), 7708-7719.

810 35. Mesomo, M. C.; Scheer, A. d. P.; Perez, E.; Ndiaye, P. M.; Corazza, M. L., Ginger (Zingiber officinale R.) extracts obtained using supercritical $\mathrm{CO}_{2}$ and compressed propane: Kinetics and antioxidant activity evaluation. The Journal of Supercritical Fluids 2012, 71, 102-109.

36. Park, H. S.; Im, N. G.; Kim, K. H., Extraction behaviors of caffeine and 815 chlorophylls in supercritical decaffeination of green tea leaves. LWT - Food Science and Technology 2012, 45 (1), 73-78. 
37. Hsu, Y.-W.; Tsai, C.-F.; Chen, W.-K.; Ho, Y.-C.; Lu, F.-J., Determination of lutein and zeaxanthin and antioxidant capacity of supercritical carbon dioxide extract from daylily (Hemerocallis disticha). Food Chemistry 2011, 129 (4), 1813-1818.

820 38. Cheah, E. L. C.; Heng, P. W. S.; Chan, L. W., Optimization of supercritical fluid extraction and pressurized liquid extraction of active principles from Magnolia officinalis using the Taguchi design. Separation and Purification Technology 2010, 71 (3), 293-301.

39. Fernández-Ponce, M. T.; Casas, L.; Mantell, C.; Rodríguez, M.; Martínez de la Ossa, E., Extraction of antioxidant compounds from different varieties of Mangifera indica 825 leaves using green technologies. The Journal of Supercritical Fluids 2012, 72, 168-175.

40. Orio, L.; Alexandru, L.; Cravotto, G.; Mantegna, S.; Barge, A., UAE, MAE, SFE$\mathrm{CO}_{2}$ and classical methods for the extraction of Mitragyna speciosa leaves. Ultrasonics Sonochemistry 2012, 19 (3), 591-595.

41. Taamalli, A.; Arráez-Román, D.; Barrajón-Catalán, E.; Ruiz-Torres, V.; Pérez830 Sánchez, A.; Herrero, M.; Ibañez, E.; Micol, V.; Zarrouk, M.; Segura-Carretero, A.; Fernández-Gutiérrez, A., Use of advanced techniques for the extraction of phenolic compounds from Tunisian olive leaves: Phenolic composition and cytotoxicity against human breast cancer cells. Food and Chemical Toxicology 2012, 50 (6), 1817-1825.

42. Ocaña-Fuentes, A.; Arranz-Gutiérrez, E.; Señorans, F. J.; Reglero, G., Supercritical 835 fluid extraction of oregano (Origanum vulgare) essentials oils: Anti-inflammatory properties based on cytokine response on THP-1 macrophages. Food and Chemical Toxicology 2010, 48 (6), 1568-1575.

43. Martín, L.; González-Coloma, A.; Díaz, C. E.; Mainar, A. M.; Urieta, J. S., Supercritical $\mathrm{CO}_{2}$ extraction of Persea indica: Effect of extraction parameters, modelling and bioactivity of its extracts. The Journal of Supercritical Fluids 2011, 57 (2), 120-128. 
44. Shi, X.; Wu, H.; Shi, J.; Xue, S. J.; Wang, D.; Wang, W.; Cheng, A.; Gong, Z.; Chen, X.; Wang, C., Effect of modifier on the composition and antioxidant activity of carotenoid extracts from pumpkin (Cucurbita maxima) by supercritical $\mathrm{CO}_{2}$. LWT - Food Science and Technology 2013, 51 (2), 433-440.

845 45. Valdés, A.; García-Cañas, V.; Rocamora-Reverte, L.; Gómez-Martínez, Á.; Ferragut, J. A.; Cifuentes, A., Effect of rosemary polyphenols on human colon cancer cells: transcriptomic profiling and functional enrichment analysis. Genes \& Nutrition 2012, 8 (1), 43-60.

46. Vicente, G.; García-Risco, M. R.; Fornari, T.; Reglero, G., Supercritical 850 Fractionation of Rosemary Extracts to Improve the Antioxidant Activity. Chemical Engineering \& Technology 2012, 35 (1), 176-182.

47. Vicente, G.; Martín, D.; García-Risco, M.; Fornari, T.; Reglero, G., Supercritical carbon dioxide extraction of antioxidant for rosemary (Rosmarinus officinalis) leaves for use in edible vegetable oils Journal of Oleo Science 2012, 61 (12), 689-697.

855 48. Vázquez, E.; García-Risco, M. R.; Jaime, L.; Reglero, G.; Fornari, T., Simultaneous extraction of rosemary and spinach leaves and its effect on the antioxidant activity of products. The Journal of Supercritical Fluids 2013, 82, 138-145.

49. Plánder, S.; Gontaru, L.; Blazics, B.; Veres, K.; Kéry, Á.; Kareth, S.; Simándi, B., Major antioxidant constituents from Satureja hortensis L. extracts obtained with different solvents. European Journal of Lipid Science and Technology 2012, 114 (7), 772-779.

50. Ansari, K.; Goodarznia, I., Optimization of supercritical carbon dioxide extraction of essential oil from spearmint (Mentha spicata L.) leaves by using Taguchi methodology. The Journal of Supercritical Fluids 2012, 67, 123-130. 
51. Akay, S.; Alpak, I.; Yesil-Celiktas, O., Effects of process parameters on 865 supercritical $\mathrm{CO}_{2}$ extraction of total phenols from strawberry (Arbutus unedo L.) fruits: An optimization study. Journal of Separation Science 2011, 34 (15), 1925-1931.

52. Santoyo, S.; Jaime, L.; García-Risco, M. R.; Lopez-Hazas, M.; Reglero, G., Supercritical fluid extraction as an alternative process to obtain antiviral agents from thyme species. Industrial Crops and Products 2014, 52, 475-480.

870 53. Zizovic, I.; Ivanovic, J.; Misic, D.; Stamenic, M.; Djordjevic, S.; Kukic-Markovic, J.; Petrovic, S. D., SFE as a superior technique for isolation of extracts with strong antibacterial activities from lichen Usnea barbata L. The Journal of Supercritical Fluids 2012, 72, 7-14.

54. Fernández-Ponce, x. T.; Casas, L.; Mantell, C.; Rodríguez, M.; Martínez de la Ossa,

875 E., Extraction of antioxidant compounds from different varieties of Mangifera indica leaves using green technologies. The Journal of Supercritical Fluids 2012, 72, 168-175.

55. Ligor, M.; Trziszka, T.; Buszewski, B., Study of Antioxidant Activity of Biologically Active Compounds Isolated from Green Vegetables by Coupled Analytical Techniques. Food Analytical Methods 2012, 6 (2), 630-636.

880 56. Shi, J.; Yi, C.; Ye, X.; Xue, S.; Jiang, Y.; Ma, Y.; Liu, D., Effects of supercritical $\mathrm{CO}_{2}$ fluid parameters on chemical composition and yield of carotenoids extracted from pumpkin. LWT - Food Science and Technology 2010, 43 (1), 39-44.

57. Farnsworth, N. R.; Akerele, O.; Bingel, A. S.; Soejarto, D. D.; Guo, Z., Medicinal plants in therapy. Bulletin of the World Health Organization 1985, 63 (6), 965-981.

885 58. Sharif, K. M.; Rahman, M. M.; Azmir, J.; Mohamed, A.; Jahurul, M. H. A.; Sahena, F.; Zaidul, I. S. M., Experimental design of supercritical fluid extraction - A review. Journal of Food Engineering 2014, 124, 105-116. 
59. Ramandi, N. F.; Najafi, N. M.; Raofie, F.; Ghasemi, E., Central Composite Design for the Optimization of Supercritical Carbon Dioxide Fluid Extraction of Fatty Acids from

60. Caldera, G.; Figueroa, Y.; Vargas, M.; Santos, D. T.; Marquina-Chidsey, G., Optimization of Supercritical Fluid Extraction of Antioxidant Compounds from Venezuelan Rosemary Leaves. International Journal of Food Engineering 2012, 8 (4).

61. Ghasemi, E.; Raofie, F.; Najafi, N. M., Application of response surface 895 methodology and central composite design for the optimisation of supercritical fluid extraction of essential oils from Myrtus communis L. leaves. Food Chemistry 2011, 126 (3), $1449-1453$.

62. Zarena, A. S.; Sachindra, N. M.; Udaya Sankar, K., Optimisation of ethanol modified supercritical carbon dioxide on the extract yield and antioxidant activity from 900 Garcinia mangostana L. Food Chemistry 2012, 130 (1), 203-208.

63. Rubio-Rodríguez, N.; de Diego, S. M.; Beltrán, S.; Jaime, I.; Sanz, M. T.; Rovira, J., Supercritical fluid extraction of fish oil from fish by-products: A comparison with other extraction methods. Journal of Food Engineering 2012, 109 (2), 238-248.

64. De Jesus Raposo, M. F.; De Morais, R. M. S. C.; De Morais, A. M. M. B., Health 905 applications of bioactive compounds from marine microalgae. Life Sciences 2013, 93 (15), $479-486$.

65. Sahena, F.; Zaidul, I. S. M.; S., J.; N., S.; H.A., J.; K.A., A.; N.A., N., PUFAs in Fish: Extraction,Fractionation, Importance in Health. Comprehensive Reviews in Food Science and Food Safety 2009, 8, 59-74. 
910 66. Rubio-Rodríguez, N.; Beltrán, S.; Jaime, I.; de Diego, S. M.; Sanz, M. T.; Carballido, J. R., Production of omega-3 polyunsaturated fatty acid concentrates: A review. Innovative Food Science \& Emerging Technologies 2010, 11 (1), 1-12.

67. Lopes, B. L. F.; Sánchez-Camargo, A. P.; Ferreira, A. L. K.; Grimaldi, R.; Paviani, L. C.; Cabral, F. A., Selectivity of supercritical carbon dioxide in the fractionation of fish 915 oil with a lower content of EPA+DHA. The Journal of Supercritical Fluids 2012, 61, 7885 .

68. Yamaguchi, K.; Murakami, M.; Nakano, H.; Konosu, S.; Kokura, T.; Yamamoto, H.; Kosaka, M.; Hata, K., Supercritical carbon dioxide extraction of oils from Antarctic krill. Journal of Agricultural and Food Chemistry 1986, 34 (5), 904-907.

920 69. Hardardottir, I.; Kinsella, J. E., Extraction of Lipid and Cholesterol from Fish Muscle with Supercritical Fluids. Journal of Food Science 1988, 53 (6), 1656-1658.

70. Tanaka, Y.; Ohkubo, T., Extraction of Lipids from Salmon Roe with Supercritical Carbon Dioxide. Journal of Oleo Science 2003, 52 (6), 295-301.

71. Golmakani, M.-T.; Mendiola, J. A.; Rezaei, K.; Ibáñez, E., Expanded ethanol with $925 \mathrm{CO}_{2}$ and pressurized ethyl lactate to obtain fractions enriched in $\gamma$-Linolenic Acid from Arthrospira platensis (Spirulina). The Journal of Supercritical Fluids 2012, 62, 109-115.

72. Sánchez-Camargo, A. P.; Meireles, M. Â. A.; Ferreira, A. L. K.; Saito, E.; Cabral, F. A., Extraction of $\omega-3$ fatty acids and astaxanthin from Brazilian redspotted shrimp waste using supercritical $\mathrm{CO}_{2}+$ ethanol mixtures. The Journal of Supercritical Fluids 2012, 61, 930 71-77.

73. Sánchez-Camargo, A. P.; Martinez-Correa, H. A.; Paviani, L. C.; Cabral, F. A., Supercritical $\mathrm{CO}_{2}$ extraction of lipids and astaxanthin from Brazilian redspotted shrimp 
waste (Farfantepenaeus paulensis). The Journal of Supercritical Fluids 2011, 56 (2), 164173.

935 74. Ruen-ngam, D.; Shotipruk, A.; Pavasant, P.; Machmudah, S.; Goto, M., Selective Extraction of Lutein from Alcohol Treated Chlorella vulgaris by Supercritical $\mathrm{CO}_{2}$. Chemical Engineering \& Technology 2012, 35 (2), 255-260.

75. Wang, H.-M.; Pan, J.-L.; Chen, C.-Y.; Chiu, C.-C.; Yang, M.-H.; Chang, H.-W.; Chang, J.-S., Identification of anti-lung cancer extract from Chlorella vulgaris C-C by 940 antioxidant property using supercritical carbon dioxide extraction. Process Biochemistry 2010, 45 (12), 1865-1872.

76. Sahena, F.; Zaidul, I. S. M.; Jinap, S.; Jahurul, M. H. A.; Khatib, A.; Norulaini, N. A. N., Extraction of fish oil from the skin of Indian mackerel using supercritical fluids. Journal of Food Engineering 2010, 99 (1), 63-69.

945 77. Wang, L.; Yang, B.; Yan, B.; Yao, X., Supercritical fluid extraction of astaxanthin from Haematococcus pluvialis and its antioxidant potential in sunflower oil. Innovative Food Science \& Emerging Technologies 2012, 13, 120-127.

78. Fujii, K., Process integration of supercritical carbon dioxide extraction and acid treatment for astaxanthin extraction from a vegetative microalga. Food and Bioproducts Processing 2012, 90 (4), 762-766.

79. Liau, B.-C.; Shen, C.-T.; Liang, F.-P.; Hong, S.-E.; Hsu, S.-L.; Jong, T.-T.; Chang, C.-M. J., Supercritical fluids extraction and anti-solvent purification of carotenoids from microalgae and associated bioactivity. The Journal of Supercritical Fluids 2010, 55 (1), $169-175$.

955 80. Treyvaud Amiguet, V.; Kramp, K. L.; Mao, J.; McRae, C.; Goulah, A.; Kimpe, L. E.; Blais, J. M.; Arnason, J. T., Supercritical carbon dioxide extraction of polyunsaturated 
fatty acids from Northern shrimp (Pandalus borealis Kreyer) processing by-products. Food Chemistry 2012, 130 (4), 853-858.

81. Tanniou, A.; Serrano, E.; Laurent, V.; Ibañez, E.; Mendiola, J. A.; Cerantola, S.; 960 Kervarec, N.; LaBarre, S.; Marchal, L.; V., S.-P., Green improved processes to extract bioactive phenolic compounds from brown macroalgae using Sargassum muticum as model. Talanta 2013, 104, 44-52.

82. Macías-Sánchez, M. D.; Fernandez-Sevilla, J. M.; Fernández, F. G. A.; García, M. C. C.; Grima, E. M., Supercritical fluid extraction of carotenoids from Scenedesmus 965 almeriensis. Food Chemistry 2010, 123 (3), 928-935.

83. Tang, S.; Qin, C.; Wang, H.; Li, S.; Tian, S., Study on supercritical extraction of lipids and enrichment of DHA from oil-rich microalgae. The Journal of Supercritical Fluids 2011, 57 (1), 44-49.

84. Aguiar, A. C.; Visentainer, J. V.; Martínez, J., Extraction from striped weakfish cost estimation. The Journal of Supercritical Fluids 2012, 71, 1-10.

85. Freitas, A. C.; Rodrigues, D.; Rocha-Santos, T. A. P.; Gomes, A. M. P.; Duarte, A. C., Marine biotechnology advances towards applications in new functional foods. Biotechnology Advances 2012, 30 (6), 1506-1515.

975 86. Herrero, M.; Mendiola, J. A.; Cifuentes, A.; Ibáñez, E., Supercritical fluid extraction: Recent advances and applications. Journal of Chromatography A 2010, 1217 (16), 2495-2511.

87. Wijngaard, H.; Hossain, M. B.; Rai, D. K.; Brunton, N., Techniques to extract bioactive compounds from food by-products of plant origin. Food Research International 2012, 46 (2), 505-513. 
88. Li, B.; Xu, Y.; Jin, Y.-X.; Wu, Y.-Y.; Tu, Y.-Y., Response surface optimization of supercritical fluid extraction of kaempferol glycosides from tea seed cake. Industrial Crops and Products 2010, 32 (2), 123-128.

89. Casas, L.; Mantell, C.; Rodríguez, M.; Ossa, E. J. M. d. 1.; Roldán, A.; Ory, I. D.; 985 Caro, I.; Blandino, A., Extraction of resveratrol from the pomace of Palomino fino grapes by supercritical carbon dioxide. Journal of Food Engineering 2010, 96 (2), 304-308.

90. Andrade, K. S.; Gonçalvez, R. T.; Maraschin, M.; Ribeiro-do-Valle, R. M.; Martínez, J.; Ferreira, S. R. S., Supercritical fluid extraction from spent coffee grounds and coffee husks: Antioxidant activity and effect of operational variables on extract composition. Talanta 2012, 88, 544-552.

91. Dermeche, S.; Nadour, M.; Larroche, C.; Moulti-Mati, F.; Michaud, P., Olive mill wastes: Biochemical characterizations and valorization strategies. Process Biochemistry 2013, 48 (10), 1532-1552.

92. Yilmaz, E. E.; Özvural, E. B.; Vural, H., Extraction and identification of 995 proanthocyanidins from grape seed (Vitis Vinifera) using supercritical carbon dioxide. The Journal of Supercritical Fluids 2011, 55 (3), 924-928.

93. Farías-Campomanes, A. M.; Rostagno, M. A.; Meireles, M. A. A., Production of polyphenol extracts from grape bagasse using supercritical fluids: Yield, extract composition and economic evaluation. The Journal of Supercritical Fluids 2013, 77, 70-78.

1000 94. Peralbo-Molina, Á.; Luque de Castro, M. D., Potential of residues from the Mediterranean agriculture and agrifood industry. Trends in Food Science \& Technology 2013, 32 (1), 16-24. 
95. Zuknik, M. H.; Nik Norulaini, N. A.; Mohd Omar, A. K., Supercritical carbon dioxide extraction of lycopene: A review. Journal of Food Engineering 2012, 112 (4), 253262.

96. Egydio, J. A.; Moraes, Â. M.; Rosa, P. T. V., Supercritical fluid extraction of lycopene from tomato juice and characterization of its antioxidation activity. The Journal of Supercritical Fluids 2010, 54 (2), 159-164.

97. Vaughn, K. L. S.; Clausen, E. C.; King, J. W.; Howard, L. R.; Danielle, J. C., 1010 Extraction conditions affecting supercritical fluid extraction (SFE) of lycopene from watermelon. Bioresource Technology 2008, 99 (16), 7835-7841.

98. Comim, S. R. R.; Madella, K.; Oliveira, J. V.; Ferreira, S. R. S., Supercritical fluid extraction from dried banana peel (Musa spp., genomic group AAB): Extraction yield, mathematical modeling, economical analysis and phase equilibria. The Journal of 1015 Supercritical Fluids 2010, 54 (1), 30-37.

99. Castro-Vargas, H. I.; Rodríguez-Varela, L. I.; Ferreira, S. R. S.; Parada-Alfonso, F., Extraction of phenolic fraction from guava seeds (Psidium guajava L.) using supercritical carbon dioxide and co-solvents. The Journal of Supercritical Fluids 2010, 51 (3), 319-324.

100. Cavalcanti, R. N.; Veggi, P. C.; Meireles, M. A. A., Supercritical fluid extraction 1020 with a modifier of antioxidant compounds from jabuticaba (Myrciaria cauliflora) byproducts: economic viability. Procedia Food Science 2011, 1, 1672-1678.

101. Nyam, K. L.; Tan, C. P.; Lai, O. M.; Long, K.; Che Man, Y. B., Optimization of supercritical $\mathrm{CO}_{2}$ extraction of phytosterol-enriched oil from Kalahari melon seeds. Food and Bioprocess Technology 2009, 4 (8), 1432-1441.

1025 102. Benelli, P.; Riehl, C. A. S.; Smânia, A.; Smânia, E. F. A.; Ferreira, S. R. S., Bioactive extracts of orange (Citrus sinensis L. Osbeck) pomace obtained by SFE and low 
pressure techniques: Mathematical modeling and extract composition. The Journal of Supercritical Fluids 2010, 55 (1), 132-141.

103. Rahman, N. N. A.; Al-Rawi, S. S.; Ibrahim, A. H.; Ben Nama, M. M.; Ab Kadir, M. 1030 O., Supercritical carbon dioxide extraction of the residual oil from palm kernel cake. Journal of Food Engineering 2012, 108 (1), 166-170.

104. Mezzomo, N.; Mileo, B. R.; Friedrich, M. T.; Martínez, J.; Ferreira, S. R. S., Supercritical fluid extraction of peach (Prunus persica) almond oil: Process yield and extract composition. Bioresource Technology 2010, 101 (14), 5622-5632.

1035 105. Romo-Hualde, A.; Yetano-Cunchillos, A. I.; González-Ferrero, C.; Sáiz-Abajo, M. J.; González-Navarro, C. J., Supercritical fluid extraction and microencapsulation of bioactive compounds from red pepper (Capsicum annum L.) by-products. Food Chemistry 2012, 133 (3), 1045-1049.

106. İçen, H.; Gürü, M., Effect of ethanol content on supercritical carbon dioxide 1040 extraction of caffeine from tea stalk and fiber wastes. The Journal of Supercritical Fluids 2010, 55 (1), 156-160.

107. Prado, J. M.; Prado, G. H. C.; Meireles, M. A. A., Scale-up study of supercritical fluid extraction process for clove and sugarcane residue. The Journal of Supercritical Fluids 2011, 56 (3), 231-237.

1045 108. Machmudah, S.; Zakaria.; Winardi, S.; Sasaki, M.; Goto, M.; Kusumoto, N.; Hayakawa, K., Lycopene extraction from tomato peel by-product containing tomato seed using supercritical carbon dioxide. Journal of Food Engineering 2012, 108 (2), 290-296.

109. Shi, J.; Yi, C.; Xue, S. J.; Jiang, Y.; Ma, Y.; Li, D., Effects of modifiers on the profile of lycopene extracted from tomato skins by supercritical $\mathrm{CO}_{2}$. Journal of Food Engineering 2009, 93 (4), 431-436. 
110. Rebolleda, S.; Beltrán, S.; Sanz, M. T.; González-Sanjosé, M. L.; Solaesa, Á. G., Extraction of alkylresorcinols from wheat bran with supercritical $\mathrm{CO}_{2}$. Journal of Food Engineering 2013, 119 (4), 814-821.

111. Sekhon, B. S., Supercritical Fluid Technology: An Overview of Pharmaceutical 1055 Applications. International Journal of PharmTech Research 2010, 2 (1), 810-826.

112. Pasquali, I.; Bettini, R., Are pharmaceutics really going supercritical? International Journal of Pharmaceutics 2008, 364 (2), 176-187.

113. Zhiyi, L.; Jingzhi, J.; Xuewu, L.; Shunxuan, Z.; Yuanjing, X.; Jian, W., Preparation of griseofulvin microparticles by supercritical fluid expansion depressurization process. Powder Technology 2008, 182 (3), 459-465.

114. Esfandiari, N.; Ghoreishi, S. M., Synthesis of 5-Fluorouracil nanoparticles via supercritical gas antisolvent process. The Journal of Supercritical Fluids 2013, 84 (0), 205210.

115. Chen, W.; Hu, X.; Hong, Y.; Su, Y.; Wang, H.; Li, J., Ibuprofen nanoparticles 1065 prepared by a PGSS ${ }^{\text {TM}}$-based method. Powder Technology 2013, 245 (0), 241-250.

116. Jung, I.-I.; Haam, S.; Lim, G.; Ryu, J.-H., Preparation of peptide-loaded polymer microparticles using supercritical carbon dioxide. Biotechnology and Bioprocess Engineering 2012, 17 (1), 185-194.

117. Tabernero, A.; Martín del Valle, E. M.; Galán, M. A., Precipitation of tretinoin and acetaminophen with solution enhanced dispersion by supercritical fluids (SEDS). Role of phase equilibria to optimize particle diameter. Powder Technology 2012, 217 (0), 177-188. 
118. Kluge, J.; Fusaro, F.; Muhrer, G.; Thakur, R.; Mazzotti, M., Rational design of drug-polymer co-formulations by $\mathrm{CO}_{2}$ anti-solvent precipitation. The Journal of Supercritical Fluids 2009, 48 (2), 176-182.

1075 119. Lesoin, L.; Crampon, C.; Boutin, O.; Badens, E., Preparation of liposomes using the supercritical anti-solvent (SAS) process and comparison with a conventional method. The Journal of Supercritical Fluids 2011, 57 (2), 162-174.

120. Kluge, J.; Joss, L.; Viereck, S.; Mazzotti, M., Emulsion crystallization of phenanthrene by supercritical fluid extraction of emulsions. Chemical Engineering Science $1080 \quad 2012,77(0), 249-258$.

121. Howell, J.; Niu, F.; McCabe, S. E.; Zhou, W.; Decedue, C. J., Solvent Removal and Spore Inactivation Directly in Dispensing Vials with Supercritical Carbon Dioxide and Sterilant. AAPS PharmSciTech 2012, 13 (2), 582-589.

122. Nejad, S. J.; Abolghasemi, H.; Moosavian, M. A.; Maragheh, M. G., Fractional 1085 factorial design for the optimization of supercritical carbon dioxide extraction of $\mathrm{La}^{3+}, \mathrm{Ce}^{3+}$ and $\mathrm{Sm}^{3+}$ ions from a solid matrix using bis(2,4,4-trimethylpentyl)dithiophosphinic acid + tributylphosphate. Chemical Engineering Research and Design 2011, 89 (6), 827-835.

123. Albarelli, J. Q.; Rabelo, R. B.; Santos, D. T.; Beppu, M. M.; Meireles, M. A. A., Effects of supercritical carbon dioxide on waste banana peels for heavy metal removal. The 1090 Journal of Supercritical Fluids 2011, 58 (3), 343-351.

124. Martín, L.; Marqués, J. L.; González-Coloma, A.; Mainar, A. M.; Palavra, A. M. F.; Urieta, J. S., Supercritical methodologies applied to the production of biopesticides: a review. Phytochemistry Reviews 2012, 11 (4), 413-431.

125. Sims, M. Liquid carbon dioxide extraction of pyrethrins. US Pat 4,281,171, 1981. 
1095 126. Cai, T. T.; Ye, M.; Li, Z. Y.; Fan, L. M.; Zha, Y. G.; Wang, J., Investigation of the main chemical compounds in pyrethrum extract obtained by supercritical fluid extraction. Advanced Materials Research 2013, 781 - 784, 737-740.

127. Chen, L.; Han, B.; Peng, L., Bioactivity of the neem seed kernel supercritical extracts towards Tribolium castaneum (Herbst). Journal of Food, Agriculture and Environment 2012, 10 (3-4), 1511-1514.

128. Zahedi, G.; Elkamel, A.; Lohi, A.; Hatami, T., Optimization of supercritical extraction of nimbin from neem seeds in presence of methanol as co-solvent. The Journal of Supercritical Fluids 2010, 55 (1), 142-148.

129. Pavela, R.; Sajfrtov, M.; Sovová, H.; Bárnet, M., The insecticidal activity of 1105 Satureja hortensis L. extracts obtained by supercritical fluid extraction and traditional extraction techniques. Applied Entomology and Zoology 2008, 43 (3), 377-382.

130. Pavela, R.; Sajfrtová, M.; Sovová, H.; Karban, J.; Bárnet, M., The Effects of Extracts Obtained by Supercritical Fluid Extraction and Traditional Extraction Techniques on Larvae Leptinotarsa decemlineata SAY. Journal of Essential Oil Research 2009, 21 (4), $1110 \quad 367-373$.

131. Liang, W.; Cheng, J.; Ma, L. Q.; Liu, Y. B.; Shi, G. L.; Wang, Y. N., Componential analysis and acaricidal activities of Stellera chamaejasme extracts by supercritical fluid extraction. In Information Technology and Agricultural Engineering, Zhu, E.; Sambath, S., Eds. Springer Berlin Heidelberg: 2012; Vol. 134, pp 643-652.

1115 132. Martín, L.; Julio, L. F.; Burillo, J.; Sanz, J.; Mainar, A. M.; González-Coloma, A., Comparative chemistry and insect antifeedant action of traditional (Clevenger and Soxhlet) and supercritical extracts $\left(\mathrm{CO}_{2}\right)$ of two cultivated wormwood (Artemisia absinthium L.) populations. Industrial Crops and Products 2011, 34 (3), 1615-1621. 
133. Catchpole, O.; Ryan, J.; Zhu, Y.; Fenton, K.; Grey, J.; Vyssotski, M.; MacKenzie,

1120 A.; Nekrasov, E.; Mitchell, K., Extraction of lipids from fermentation biomass using nearcritical dimethylether. The Journal of Supercritical Fluids 2010, 53 (1-3), 34-41.

134. Planeta, J.; Roth, M., Solute Partitioning between the Ionic Liquid 1-n-Butyl-3methylimidazolium Tetrafluoroborate and Supercritical $\mathrm{CO}_{2}$ from Capillary-Column Chromatography. The Journal of Physical Chemistry B 2005, 109 (31), 15165-15171.

1125 135. Catchpole, O.; Tallon, S.; Dyer, P.; Montanes, F.; Moreno, T.; Vagi, E.; Eltringham, W.; Billakanti, J., Integrated Supercritical Fluid Extraction and Bioprocessing. American Journal of Biochemistry and Biotechnology 2012, 8 (4), 263-287. 